Int. J. Dev. Biol. 53: 909-924 (2009)

doi: $10.1387 / \mathrm{ijdb} .082747 \mathrm{rb}$

\title{
A twist of insight - the role of Twist-family bHLH factors in development
}

\author{
RALSTON M. BARNES and ANTHONY B. FIRULLI* \\ Riley Heart Research Center, Wells Center for Pediatric Research, Division of Pediatric Cardiology, \\ Departments of Anatomy and Medical and Molecular Genetics, Indiana Medical School, Indianapolis, IN, USA
}

\begin{abstract}
Members of the Twist-family of bHLH proteins play a pivotal role in a number of essential developmental programs. Twist-family bHLH proteins function by dimerizing with other bHLH members and binding to cis- regulatory elements, called E-boxes. While Twist-family members may simply exhibit a preference in terms of high-affinity binding partners, a complex, multilevel cascade of regulation creates a dynamic role for these bHLH proteins. We summarize in this review information on each Twist-family member concerning expression pattern, function, regulation, downstream targets, and interactions with other bHLH proteins. Additionally, we focus on the phospho-regulatory mechanisms that tightly control posttranslational modification of Twist-family member bHLH proteins.
\end{abstract}

KEYWORDS: Twist1, Twist2, Hand1, Hand2, Paraxis, Scleraxis, limb, heart, trophoblast, phosphoregulation, dimerization

The Twist-family of basic helix-loop-helix (bHLH) factors is an evolutionarily conserved family of proteins that play diverse roles in both embryonic development and pathological disease. These diverse roles are reflected in the functional mechanisms that govern Twist-family biological activity. The requirement of bHLH factors to form a dimer complex is well established and recently a number of groups have shown that Twist family proteins have broad sets of potential dimer partners. In addition to Class A bHLH factors (E-proteins), homodimerization and heterodimerization between Twist-family members form important and functional dimer complexes that are required for proper development. Given the broad partially overlapping expression patterns of Twist factors observed within the developing embryo and the potential of these factors to form numerous unique transcriptional complexes, the spatio-temporal transcriptional regulation of Twistfamily members is a key component of the functional regulation defining specification and differentiation. Additionally, phosphorylation of conserved threonine and serine residues within the first amphipathic $\alpha$-helix of Twist-family proteins exerts a second level of control, effecting protein dimer affinities with potential partners as well as dictating DNA-binding affinities in a cis-element dependent manner. Moreover, phosphoregulation can regulate protein localization within the cell thereby positioning the Twist protein (and perhaps its partner) in a functional or non-functional environment. Given the recent new insights into the developmental and functional understanding of Twist factors this review strives to integrate what is known about function and mechanism.

\section{The bHLH domain}

The bHLH secondary structure is a protein dimerization-DNA binding domain that represents an evolutionarily conserved super family of near 100 transcription factors (Massari and Murre, 2000). Structurally, the motif consists of a short stretch of basic amino acids followed by an amphipathic $\alpha$-helix, a loop of varying length, ending in a second amphipathic $\alpha$-helix. The hydrophobic face of the helix makes protein-protein contacts with another bHLH factor creating a dimer. The two basic domains are then juxtaposed creating a complete DNA-binding domain. bHLH factors play essential roles in myogenesis, neurogenesis, and $\mathrm{B}$ cell development to name several examples. Twist was discov-

\footnotetext{
Abbreviations used in this paper: AER, apical ectodermal ridge; Anf, atrial natriuretic factor; bHLH, basic helix-loop-helix; D-V, dorsal-ventral; DBH, dopamine $\beta$-hydroxylase; Edn1, endothelin-1; FRET, fluorescent resonance energy transfer; HDAC, histone deacetylase; EMSA, electrophoretic mobility shift assay; MET, mesenchymal-to-epithelial transition; P11, placental lactogen 1; PKA/PKC, protein kinase A/C; PP2A, protein phosphatase 2A; SCS, saethre-chotzen syndrome; Shh, sonic hedgehog; ZPA, zone of polarizing activity.
}

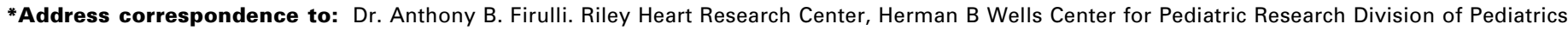
Cardiology, Departments Anatomy and Medical and Molecular Genetics, Indiana Medical School, 1044 W. Walnut St., Indianapolis, IN 46202-5225, USA Fax: +1-317-278-9298. e-mail: tfirulli@iupui.edu - web: http://www.heartresearch.iupui.edu/
}

Accepted: 10 October 2008. Published online: 6 April 2009.

ISSN: Online 1696-3547, Print 0214-6282

(c) 2009 UBC Press

Printed in Spain 
ered in Drosophila and is the founding member of a subfamily of bHLH proteins based on amino acid identity and conservation in the bHLH domain (Castanon and Baylies, 2002). We focus here on the Twist subclass of bHLH proteins and their known roles and the molecular mechanisms known to orchestrate these roles.

\section{Twist is a master regulator of cell fate in Drosophila}

Twistencodes a tissue-restricted bHLH protein originally identified in Drosophila. Twist was first implicated in the DorsalVentral (D-V) patterning of the early embryo when Twist mutants were shown to undergo abnormal gastrulation (Thisse et al., 1987). Additionally, it was later revealed that twist is required during multiple stages of embryonic development serving as a mesodermal-determining factor (Bate et al., 1991; Baylies and Bate, 1996; Cripps and Olson, 1998; Castanon and Baylies, 2002,). Immediately obvious from these studies was that twist expression is regulated in a dosage dependent manner.

During early gastrulation in Drosophila, twist is the first gene detected throughout the presumptive mesoderm, which is initially defined by a nuclear gradient of the dorsa/transcription factor (Zinzen etal., 2006). High levels of dorsa/results in the upregulation of twistas well as the gene coding for the Zn-finger protein Snail, which together cooperate with dorsal to pattern ventral cell invagination to form the mesoderm (Leptin, 1999; Ip and Gridley, 2002; Stathopoulos et al., 2002). Mutants for either twistor snail fail to undergo a ventral invagination and lack mesodermal tissue (Ganguly et al., 2005; Seher et al., 2007). Despite their inability to form any mesoderm, twist mutant embryos briefly manifest the invagination indicative of the mesodermal primordium (Seher et al., 2007) although this has been attributed to a transient activation of snailin a narrow band of mesodermal progenitors.

In addition to snail, critical twist targets include the mesodermal transcription factors dmef2, tinman, fog, transmembrane protein 448 , microRNA mir-1, and the FGF receptor heartless (Cripps et al., 1998; Sokol and Ambros, 2005; Kolsch et al., 2007; Laursen et al., 2007). Recently, ChIP-on-CHIP experiments have identified over 500 target genes for twist, including genes required for muscle development, cell proliferation, morphogenesis, and cell migration, illustrating an essential role for twistin establishing multiple transcriptional networks (Sandmann et al., 2007). Furthermore, the finding that nearly fifty percent of twist target genes have two or more twist enhancer binding sites potentiates that multiple and possibly different Twist dimers participate in combinatorial binding of these enhancers and together participate in essential and complex transcriptional regulation of target genes (Sandmann et al., 2007).

Following mesodermal induction, twist expression is dynamically regulated throughout the prospective mesoderm where twist becomes differentially expressed in both high and low dosage in the mesodermal segments (Baylies and Bate, 1996). The disparity in gene dosage of twist throughout these mesodermal segments is essential for normal development. Twist maintains a wide network of regulation that is particularly influenced by the potential dimer partners available, thus modulation of its expression will alter its availability for dimerization with its potential bHLH partners. One important dimer partner is the class I E-protein daughterless. Daughterless is capable of dimerizing with numerous bHLH factors (Van Doren et al., 1991; Giebel et al., 1997;
Castanon et al., 2001; Jafar-Nejad et al., 2006) and is expressed in a uniform pattern throughout the presumptive mesoderm while twistexpression is dynamically modulated. Electrophoretic mobility shift assays (EMSA) showed that Twist binds to DNA as either a homodimer or as a Twist-Daughterless heterodimer; opening the possibility for these two Twist transcriptional complexes to convey different developmental impacts.

A series of gain-of-function experiments that employ forced dimerization of Twist with itself or with Daughterless by utilizing a glycine-serine linker, which effectively "tethers" two bHLH proteins as a single head-to-tail polypeptide, were carried out to investigate the role of potential Twist and Daughterless dimers (Castanon et al., 2001; Castanon and Baylies, 2002). Experiments in which Twist-Daughterless heterodimers were ectopically expressed in the mesoderm of transgenic flies leads to a severe reduction in somatic musculature coupled with patterning defects (Castanon et al., 2001). Conversely, over-expression of Twist-Twist homodimers leads to the formation of ectopic somatic muscle (Castanon et al., 2001). These antagonistic results, suggest that Twist homodimers and Twist-Daughterless heterodimers modulate distinct developmental programs. In twist mutants, expression of Twist-Twist homodimers rescues only the early mesodermal and migratory defects associated with Twist loss-offunction (Castanon et al., 2001). Twist-homodimers failed to rescue the later onset patterning defects (Castanon et al., 2001). These data show that although Twist-homodimers are essential for mesodermal induction they are not sufficient for mediation of all Twist developmental functions, supporting the idea that Twist dimer regulation is a critical regulatory mechanism that modulates biological function.

When considering that twist expression is dynamically modulated within regions of the embryo (Baylies and Bate, 1996) while Daughterless is ubiquitously expressed at a uniform level (Cronmiller and Cummings, 1993), one would predict that in regions where twist is expressed at high levels (such as somatic mesoderm) Twist homodimers would prevail whereas in regions where twist is expression is less robust, there would be a higher probability of forming a Daughterless heterodimer, thus repressing somatic muscle development.

Validation for such a gene dosage model is observed by crossing flies heterozygous for either daughterless or twist concurrent with over expression of the other bHLH factor (Castanon et al., 2001). Heterozygous daughterless and twist flies do not exhibit any mutant phenotypes. As predicted, ectopic expression of twiston a heterozygous daughterless background results in an increase of ectopic somatic muscle then what is observed from Twist expression in wild type flies (Castanon et al., 2001). Ectopic expression of daughterless on a twist heterozygous background resulted in an increased suppression of mesoderm development, compared to that observed at normal twist gene dosage (Castanon et al., 2001). Thus, the overall expression of twistand daughterless (and perhaps other bHLH factors) within a given cell can act as a molecular switch that modulates transcriptional program.

While the gene dosage model illustrates daughterless and twist genetically interact, promoter analysis reveals some functional mechanism for the twist-twist and twist-daughterless dimers. Coexpression of a mef2 mesoderm-specific luciferase reporter with either daughterless-twist or twist-twist tethers shows that twist tethered homodimers robustly activates the mef2 reporter 
whereas twist-daughterless heterodimers repressed transcription (Castanon etal., 2001), thus refined dimer regulation appears critical for normal expression of the desired gene program.

While twist expression declines during the later stages of embryonic muscle development, twist persists in a select group of myogenic progenitors fated to contribute to adult muscles during metamorphosis (Bate and Arias, 1991; Bate et al., 1991; Currie and Bate, 1991). Twist is maintained in these larval progenitors until myoblasts fuse and differentiate into adult thoracic flight muscles. Though differentiation of these larval myoblasts can initiate in twist knockouts, loss of twist function results in an inability of these myoblast progenitors to undergo differentiation (Cripps and Olson, 1998). The requirement for twist in these larval myoblasts is strikingly similar to the function of twist

\section{Twist1 can regulate EMT during cancer}

In addition to its role in embryogenesis, Twist1 plays important functions in cancer (Ma et al., 2007; Yang et al., 2004; Yang et al., 2008). Twist1 is expressed in mesenchymal cell populations, a transitional population present during development, which strikingly possesses many of the same migratory characteristics that cancer cells acquire during metastasis (Acloque et al., 2008). Epithelial-to-mesenchymal transition (EMT) is the process whereby structured epithelial cells lose polarity and acquire mesenchymal features, allowing for cell movement (Zavadil and Bottinger, 2005). While EMT is essential during embryonic developmental, EMT is deleterious in neoplastic disease as it allows cancer cells to emigrate away from the primary tumor and form metastatic tumors (Thiery, 2002). Increased Twist1 expression directly corresponds to cell EMT, and it is not surprising that Twist 1 expression is an indicator of poor outcome in a number of cancers, (Hoek et al., 2004; Kwok et al.; 2005, Kyo et al., 2006).

Subtractive screens utilizing four clonal breast cancer cell lines isolated from a single mouse mammary tumor (Aslakson and Miller, 1992), which exhibit varying degrees of metastasis formation (Yang et al., 2004), revealed differential expression of Twist1 mRNA (Yang et al., 2004). Twist1 expression correlated with loss of epithelia markers such as E-cadherin induced an up regulation of mesenchymal marker genes and consequently mesenchymal cell phenotype (Yang et al., 2004). Most striking RNAi mediated knockdown of Twist1 expression within the highly metastatic 4T1 cell line greatly reduced metastasis formation in the lung, suggesting that Twist 1 acts as master regulator of EMT and if properly regulated could inhibit secondary tumor formation.

A potential mechanism that accounts for Twist1 upregulation in tumors comes from a study showing that Hypoxia inducible factoralpha (HIF1- $\alpha$ ) binds to a hypoxia responsive cis-element (HRE) within the Twist1 proximal promoter (Yang et al., 2008). Intratumoural hypoxia is an important mechanism responsible for promoting metastasis (lyer et al., 1998; Ryan et al.; 1998; Yang et al., 2008). Downstream targets for Twist1 also mediate tumor progression. MicroRNA mir-10b is highly expressed in cancer, exclusively restricted to metastatic cells (Ma et al., 2007). Chromatin immunoprecipitation (ChIP) assays demonstrate that Twist1 directly regulates mir-10b via binding to the promoter of microRNA mir-10b, located in an intron of the Hox D cluster (Ma and Weinberg, 2007). Mir-10b expression represses translation of HoxD10, permitting the expression of the pro-metastatic gene product RhoC, which promotes cancer cell migration and invasion. Validation of this proposed mechanism is observed with siRNA silencing of miR-10b as under these conditions Twist-mediated cell migration and invasion in breast cancer cells is inhibited (Ma et al., 2007; Ma and Weinbera. 2007). during early embryonic development, where it serves as an essential cofactor and mesodermal regulator of downstream factor controlling myogenesis.

\section{The role of Twist in vertebrates}

The vertebrate homologue, Twist1, shares a high degree of amino acid identity to Drosophila twist; however, its functional role in mammals reflects its expression profile. While twist is necessary for gastrulation and is expressed in the prospective mesoderm, Twist1 expression in the mouse is not detected until after gastrulation initiates. At E7.0-7.5 Twist1 expression is first detected in the extra embryonic mesoderm and is strongly expressed in the allantois (Fuchtbauer, 1995). After E7.5 Twist1 is reported in the head mesenchyme, somites, and somatic lateral plate mesoderm (Fuchtbauer, 1995). AT E8.5 Twist1 continues to be strongly expressed in the head mesenchyme and is also detected in the first pharyngeal arch (Fuchtbauer, 1995). Interestingly, Twist 1 protein is not detected until almost E8.5 despite the earlier expression pattern, which coincides with the first reported phenotypic abnormalities in Twist1 null mice (Chen and Behringer, 1995; Gitelman, 1997). At E9.5 Twist1 is expressed in the cranial mesenchyme, cephalic and thoracic neural crest, pharyngeal arches, sclerotomal mesoderm, somatopleuric mesoderm, and throughout the rostral and caudal margins of the limb bud mesenchyme underlying the apical ectodermal ridge (AER) (Wolf et al., 1991; Fuchtbauer, 1995; Stoetzel et al., 1995; Gitelman, 1997). Between E16-E18 Twist1 expression is detected in developing osteoblasts, in the cranial mesenchyme, in the primordial of the tooth mesenchyme, and in the atrioventricular cushions (Fuchtbauer, 1995; Bialek et al., 2004).

Given that Twist functions as a mesodermal specifier in Drosophila it is surprising that Twist1 expression follows mesodermal induction in mice. In further contrast, Twist1 functionally represses muscle development by sequestering E-proteins from forming functional myogenic complexes with the skeletal muscle specific bHLH factor, MyoD, functionally blocking both cis- and trans-MyoD elements, and by inhibiting transactivation of Mef2 (Hebrok et al., 1994; Spicer et al., 1996; Hamamori et al., 1997). To gain additional insight into the function of Twist 1 in the mouse, Twist1 knockouts were generated (Chen and Behringer, 1995). Twist1 null embryos die at E11.5, displaying exencephaly, pharyngeal arch and somitic defects, as well as defects in both cranial and cardiac neural crest cell populations (Chen and Behringer, 1995; Rice et al., 2000; Soo et al., 2002; Ishii et al., 2003; Connerney et al., 2006; Connerney et al., 2008; Vincentz et al., 2008). It is thought that the cranial mesenchyme plays a non-cell autonomous role in neural tube formation by either shaping or cushioning the neural folds and/or acting as a source of secreted factors (Chen and Behringer, 1995). Twist1 nulls exhibit abnormal segregation and compaction of mesenchymal cell types, cell survival and proliferation deficiencies of mesodermally specified cell populations, and hypoplastic limb buds (Chen and Behringer, 1995; O'Rourke et al., 2002; O'Rourke and Tam, 2002).

Twist1 is expressed in osteoprogenitors of the mid sutural mesenchyme of the developing cranial sutures (Rice et al., 2000). Twist1-heterozygous mice experience fusion of the coronal suture, which never occurs in wild-type mice (Bourgeois et al., 1998). Unfortunately, Twist1-null embryos die prior to osteogen- 
A

\section{Scleraxis Paraxis Twist 2 Hand 2}

Hand 1

Scleraxis Paraxis

Twist 2

Twist 1

Hand 2

Hand 1

Scleraxis

Paraxis

Twist 2

Twist 1

Hand1

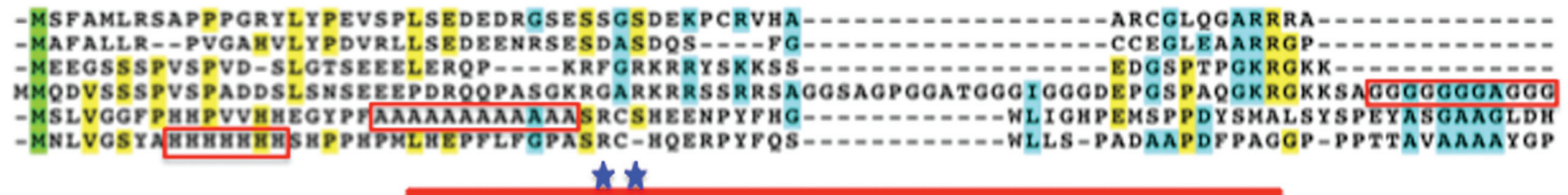

-GGRRAAGGPGPGGRPGREPRQRHTANARERDRTNSVNTAFTALRTLIPTEPADRKLSKIETLRLASSYISHLGNVLLVGEACGDGQPC -G--PGSGRRASNGAGPVVVVRQRQAANARERDRTQSVNTAFTALRTLIPTEPVDRKLSKIETLRLASSYIAHLANVLLLGDAADDGQPC ----GSPSAQSFEELQSQRILANVRERQRTQSLNEAFAALRI PTLPSD-KLSKIQTLKLAARYIDFLYQVLQSDEMDNKMTSC GGGGGGSSSGGGSPQSYEELQTQRVMANVRERQRTQSLNEAFAALRKI I PTLPSD-KLSKIQTLKLAARYIDPLYQVLQSDELDSKMASC SHYGGVPPGAGPPGLGGPRPVKRRGTANRKERRRTQSINSAFAELRECIPNVPADTKLSKIKTLRLATSYIAYLMDLLAKDDQNGEAEAF DARPSQSPGR-LEALG-SRLPKRKGSGPKKERRRTESINSAFAELRECIPNVPADTKLSKIKTLRLATSYIAYLMDVLAKDAQAGDPEAF

HSGPAFFHSGRAGS PLPPPPPPPDLARDGGENTQPKQICTFCLSNQRKLSKDRDRK---1-- -TAIRS--FR----AAGGGKSAVP-----AAADG---RQPRSICTFCLSNQRKGGSRRDLGGSCLKVRGVAPLRGPRR S-10-0S KAEIKKTD-VKEEKRKK-:
B

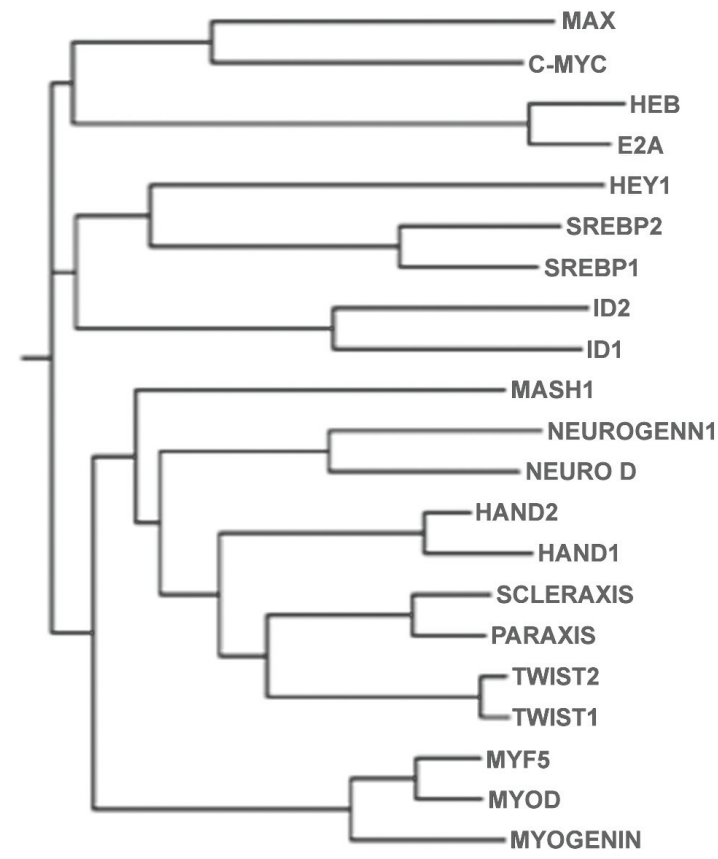

Fig. 1. Identity and conservation among Twist-family member bHLH's. (A) Predicted Protein structure of all six Twist-family bHLH members with the basic-helix-loop-helix (bHLH) domain indicated (Red Bar). The entire Twist-family shares a very high degree of conservation across the functional bHLH domain, including serine and threonine residues located in the first $\alpha$-helix which undergo phosphorylation, directly regulating dimerization and functionality (blue stars). Many Twist-family members have unique stretches of amino acids located outside of the bHLH domain in either the $\mathrm{N}$-or $\mathrm{C}$-terminus (red boxes). (B) A phylogenetic tree of a CLUSTALW alignment of bHLH domains across Twist-family members and other bHLH and HLH domain containing proteins. Twist-family members show relatively high conservation between the functional bHLH domain when compared with other bHLH sub-families.

esis. Potentially, use of the conditional Twist1 mutant may allow for further LOF analysis of the role of Twist 1 in cranial suture development (Chen et al., 2007).

Twist1 has been implicated in FGF-signaling in the cranial mesenchyme where FGF2 can induce Twist1 and inhibit Bsp, an osteoblast differentiation marker, in addition to modulating FGFr2 expression, which is expressed in proliferating osteogenic tissue (Johnson et al., 2000; Rice et al., 2000; Yoshida et al., 2005).
Calvarial organ culture showed that administration of a morpholino-mediated knockdown of Twist 1 causes premature differentiation with narrow sutural spaces and premature bone fusion (Yoshida et al., 2005). Additionally, Twist1 is able to interact with Runx2; a protein that regulates osteoblast development, via a Twist1 C-terminal domain whereby it represses osteogenesis (Bialek et al., 2004). Mutations in the C-terminal anti-osteogenic domain of Twist1 have been linked to patients with isolated cranial synostosis (Seto et al., 2007). The osteogenic repressive activity of Twist1 has been suggested to be limited to Twist1-E protein heterodimers. Twist1-E protein heterodimers have been shown to inhibit osteoblast differentiation and FGFR2 while Twist1 homodimers have been shown to promote osteoblast differentiation and up regulate FGFR2 (Connerney et al., 2006; Connerney et al., 2008). The cranial suture abnormalities that occur in Twist1heterozygous mice are possible due to alterations in the dimer balance, favoring an increase in homodimer formation throughout the sutures (Connerney et al., 2008).

Twist1 haploinsufficient mice are viable, and phenotypically model the autosomal dominant, variably penetrant human disease Saethre-Chotzen Syndrome (SCS; OMIM 101400). SCS is characterized by a broad set of facial and skeletal malformations including craniosynostosis, low frontal hairline, facial asymmetry, ptosis, deviated nasal septum, brachydactyly, and polydactyly (Jabs, 2004; Lee et al., 2002). Indeed, TWIST1 mutations are present in $80 \%$ of SCS cases with 73 independent TWIST1 mutations identified ranging from single point mutations to large chromosomal deletions (Johnson et al., 1998; Gripp et al., 2000; Jabs, 2004). Of note, the number of SCS alleles that are point mutations that result in amino acid substitutions within the functional bHLH domain of the protein suggesting that dimer regulation defects could in part mediate SCS.

Twist-family bHLH proteins have highly evolutionarily conserved serine and threonine residues located in the first $\alpha$-helix domain directly juxtaposed to the basic DNA binding domain (Fig. 1) (Firulli et al., 2003; Firulli et al., 2005). Twist-family members can be phosphoregulated by the actions of protein kinase $A(P K A)$ and PKC and the trimeric protein phosphatase 2A (PP2A) containing the $\beta 56 \delta$ regulatory subunit. Dimer partner choice of Twistfamily members can be modulated by phosphoregulation of these conserved residues, as was shown initially in studies of Hand1 (see below) (Fig. 2) (Castanon etal., 2001; Castanon and Baylies, 2002; Firulli etal., 2003; Firulli etal., 2005; Connerney et al., 2006; 
Firulli et al., 2007; Connerney et al., 2008).

A subpopulation of TWIST1 SCS point mutant alleles code for proteins that show a potential disruption of phosphoregulation (Firulli et al., 2005). Direct assessment of PKA phosphorylation within Twist 1 proteins coded by these SCS alleles confirms a reduced phosphorylation by PKA. Moreover, Fluorescence Resonance Energy Transfer (FRET) analysis of both hypophosphorylated and phosphorylation mimics of Twist1 confirm that Twist 1 dimer affinity is altered for itself and its potential bHLH partners in the developing limb E12 and Hand2 (Firulli et al., 2005).

Since haploinsufficiency of Twist 1 results in $42 \%$ penetrance of polydactyly in mice, it is interesting to note that gain-offunction expression of the Twist-family protein Hand2 phenocopies Twist 1loss-of-function (Charite et al., 2000; FernandezTeran et al., 2000). Given that gene dosage phenotypes for Twist are observed in the fly, this observation suggests that Twist1 and Hand2 might act antagonistically in their roles limb patterning. When Twist1 and Hand2 heterozygous mice are intercrossed, thereby rebalancing the gene dosage of each gene to 1 allele each, the reduction of Hand2 gene dosage completely rescues the Twist1-mediated polydactyly (Firulli $e t$ al., 2005). Moreover in gain-of-function studies where over expression of Hand2 results in polydactyly, co expression of wild type Twist 1 partially rescues this phenotype whereas expression of a hypophosphorylation Twist 1 mutant that corresponds to a TWIST1 SCS allele fails to rescue the Hand2 induced polydactyly. Together, these data support the hypothesis that phosphoregulation of these evolutionarily conserved Helix I residues modulates Twist1 dimer choice and that in addition to the overall level of bHLH gene expression, posttranslational modifications further regulate Twist-family dimer choice and thus function during development (Firulli et al., 2005).

To further explore the functional role of Twist 1 dimer choice, the Prx 1 limb-specific promoter was used to drive expression of Twist1 phosphorylation mutants and specific tethered Twist1 dimer complexes. Expectantly, unique limb phenotypes were associated with phosphoregulation state and specific Twist1 transcriptional complexes (Firulli et al., 2007). Expression of the wild-type Twist1 resulted in medial limb defects associated with reduced ossification. Consistent with its haploinsufficient effect in SCS, expression of hypophosphorylated Twist 1 resulted in milder gain-of-function phenotypes whereas expression of a phosphorylation mimic Twist1, resulted in a severe reduction in ossification, distorted limb patterning, and medial limb truncation (Firulli et al., 2007).

Expression of Twist1-Twist1, Twist1-E12 and Twist1-Hand2 tethered dimers in the limb mirrored the effect of expressing Twist1 phosphorylation mutants (Firulli et al., 2007). Transgenic expression of Twist1-E12 heterodimers produced limb defects similar to expression of wild type Twist 1 monomer whereas, expression of Twist1-Twist1 homodimers resulted in limb phenotypes similar to expression of hyperphosphorylated Twist1. Interestingly, Twist1-Hand2 dimer expression resulted in preaxial polydactyly as well as mild medial limb defects suggesting that this non-E-protein heterodimer conveys instructions observed in both Hand2 over expression and Twist1 haploinsufficiency. Whether this dimer complex plays a bona-fide role in develop- ment or is simply an inappropriate dimer complex resulting from abnormal regulation is a question that is currently unanswered.

\section{Twist2 directs development of dermal and chondro- genic tissue}

Twist2 (formerly Dermo 1) is a bHLH factor identified from a Yeast two-hybrid screen using the bHLH factor E12, as bait (Staudinger et al., 1993). Twist2 shows a very high degree of identity with Twist1. In particular, there is a high degree of conservation in the C-terminus and within the bHLH domains where there is only three amino acids not conserved (Fig. 1) (Li et al., 1995; Perrin-Schmitt et al., 1997). Consistent with all Twistfamily proteins there is low conservation of amino acids between the N-terminus and both the 5'- and 3'-UTR's.

Although spatial expression patterns of Twist2 during mouse embryogenesis demonstrate extensive overlap with Twist1, Twist2 temporally follows expression of Twist1 (Wolf et al., 1991; Li et al., 1995; Lee et al., 2000). Twist2 expression is first detected at E10.5 within the mesenchymal cell populations in the sclerotome, myotome, dermatome, branchial arches, and limb bud (Li et al., 1995). Expression becomes further restricted to mesodermally derived cartilage and dermal tissues by E15.5. Twist2 expression continues to increase in dermal tissues up to E17.5 and is then downregulated in the adult (Li et al., 1995). Lineage trace analysis confirms that Twist2 is restricted to sclerotomal mesenchyme, which develops into chondrocytes in growth plate cartilage and in perichondrium, periostium, and endosteum (Yu et al., 2003).

Twist2 knockout mice reveal remarkable phenotypes with abnormalities in the development of vertebrate; wound healing, and hair regeneration (Gong and Li, 2002; Sosic et al., 2003). These mice display severe postnatal atrophy of multiple tissues, apoptosis, and ultimately die perinatally due to cachexia. This may be partly due to the role for Twist2 in antagonizing p53dependent apoptosis (Maestro et al., 1999). Twist2 also functions downstream of $\mathrm{NF}_{{ }_{k}} \mathrm{~B}$ by directly repressing the cytokine p65 promoter (Sosic et al., 2003). Consequently, Twist2 null mice exhibit an increased proinflamatory cytokine gene expression, which likely mediates the cachectic phenotype. Cytokine inhibition appears to be sensitive to Twist-family gene dosage as Twist1 and Twist2 compound heterozygotes recapitulate the Twist2-null cachectic phenotype (Sosic et al., 2003).

In osteogenesis Twist2 plays a distinct role preventing differentiation of preosteoblasts (Lee et al., 2000; Gong and Li, 2002). Over expression of BMP2within osteoblast progenitor cells leads to a down regulation of Twist2, further confirming a role in maintaining the unspecified state (Tamura and Noda, 1999). Twist2 is also an ADD1/SREBP1c interacting protein that is able to suppress transcriptional activity of ADD1/SREBP1c, thus playing a role in fatty acid synthesis (Lee et al., 2003). Finally, Twist2 is able to directly repress MyoD via dimer formation and Twist2 can directly associate with Mef2 factors repressing the Mef2 transactivation domain via a mechanism that is dependent on the Twist2 HLH and C-terminal domains (Gong and Li, 2002).

\section{Paraxis regulates somite morphogenesis}

The Twist family member Paraxis has been shown to regulate morphogenic events during somitogenesis. Paraxis is first ex- 
1. Level of Expression Sets The bHLH Dimer Pool
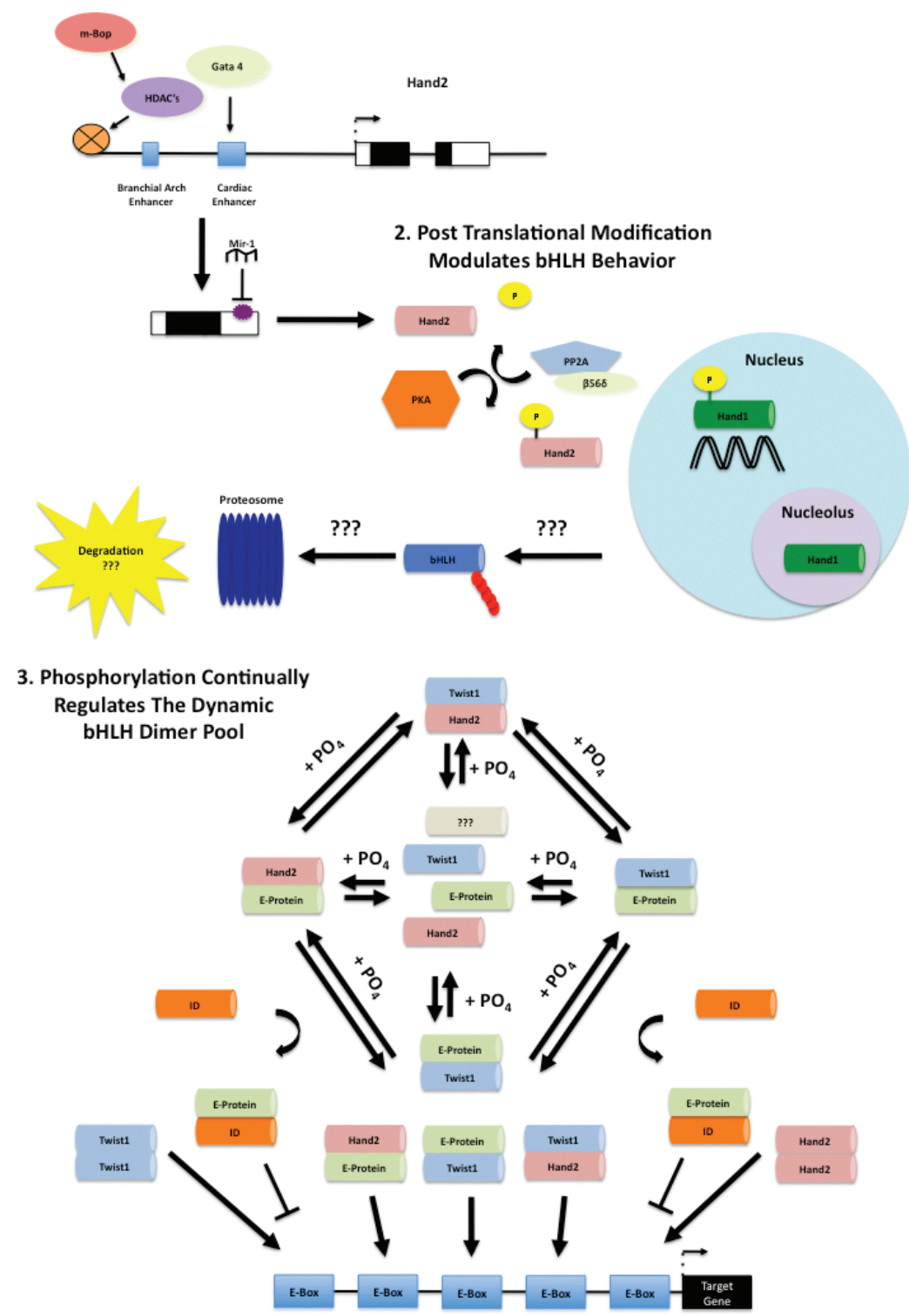

Fig. 2. Regulation and function of Twist-family bHLH members. Twist-family bHLH's undergo several layers of regulation to tightly regulate their function. Principally, transcriptional regulation establishes the spatial and temporal expression within the cell, thereby establishing the potential bHLH dimer pool within each cell (1). Hand2 transcriptional regulation has been well documented and serves as a prime example of the degree of transcriptional regulation associated with Twist-family members. Multiple tissue specific enhancer elements, such as the separate branchial arch enhancer and the heart enhancer, directly regulate spatial and temporal transcription of Hand2. The Hand2 cardiac enhancer is directly bound by Gata4, regulating ventricular expression (McFadden et al., 2000). Availability of these enhancers is dependent on their accessibility, which is tightly regulated by chromatin conformation. $m$-Bop, recruits HDACs which deacytlate specific lysine residues promoting chromatin condensation and gene silencing of Hand2 (Gottlieb et al., 2002). Hand2 mRNA can be regulated post transcriptionally by microRNAs. Mir-1 is capable of binding to the 3'UTR of the Hand2 mRNA, resulting in the silencing of the transcript and having a direct impact on the Hand2 dosage (Zhao et al., 2007; Zhao et al., 2005). Following translation, modifications can occur to the protein resulting in changes to the behavior of bHLH's (2). Protein kinase's, including PKA (pictured) and $P K C$, and the $\beta 56 \delta$ subunit of Protein Phosphatase $2 A$ (PP2A) are capable of regulating the phosphorylation state of conserved serine and threonine residues of Twist-family bHLH's (Firulli et al., 2003). Phosphorylation of Hand1 has been shown to result in alterations of cellular localization and directly affecting the activity and accessibility of the bHLH protein (Martindill et al., 2007). Dephosphorylated Hand 1 is sequestered away in the nucleolus, remaining inactive. Upon phosphorylation, Hand1 is released from the nucleolus allowing it to dimerize and bind to cis- regulatory units on target genes. Although they have not been explored, multiple forms of posttranslational modification, such as ubiquitination and protein degradation, are possible and likely regulate both protein behavior and the equilibrium of the bHLH dimer pool. Once the pool of bHLH proteins is established, an antagonistic competition for dimer partners is closely regulated by the transitional phosphorylation state of the protein (3). Phosphorylation state has a direct affect on dimer partner choice of $\mathrm{bHLH}$ proteins within the $\mathrm{bH} L \mathrm{H}$ dimer pool (Firulli et al., 2003). FRET analysis shows that a phosphorylated form of Twist1 has the highest affinity for Hand2 while having a low affinity for Twist1-homodimerization (Firulli et al., 2005). In contrast, a dephosphorylated form of Twist 1 has the lowest affinity for dimerization with Hand2 and instead has a preference for Twist1-homodimers (Firulli et al., 2005). While the phosphoregulatory circuitry closely regulates bHLH dimer choice, ID-proteins, a class of HLH passive inhibitory proteins, can sequester away E-proteins, altering the bHLH dimer pool and potentially establishing a preference for homodimers among Class B bHLH's (Massari and Murre, 2000). Once dimerized, bHLH proteins can bind tightly to E-Boxes (CANNTG) located in target genes. Target genes may contain multiple E-Boxes, which can be transactivated by select dimer pairs. Dimer partner choice is particularly important since it can directly alter the function of bHLH proteins. In the fly, Twist-homodimers are capable of directing a mesodermal fate while Twist-E-Proteinheterodimers can directly antagonize the mesodermal lineage (Castanon et al., 2001).

pressed at E7.5 in a subdomain of primitive mesoderm located caudal to both the cranial and cardiac mesodermal primordia (Burgess et al., 1995). Between E8.0 to E12.5, Paraxis expression proceeds in a rostral to caudal wave within the paraxial mesoderm, in newly formed epithelial somites (Burgess et al., 1995). Following compartmentalization of the somitic mesoderm, Paraxisis expressed in the dermomyotome, sclerotome, \& briefly within the myotome (Burgess et al., 1995). In the mature somite, Paraxis expression is downregulated with expression gone after
E13.5. Paraxis is also expressed in the fore limb buds at E10.5 in cell that are potentially myogenic progenitors that originated from the ventral edge of the dermomyotome as shown by chickquail grafting experiments (Olson and Rosenthal, 1994; Burgess et al., 1995).

Paraxis is critical to direct and maintain the epithelial characteristics of the somite, in particular the dermomyotome, acquired during the mesenchymal-to-epithelial transition (MET) necessary for somite maturation (Wilson-Rawls et al., 1999; 
Locascio and Nieto, 2001). Paraxis is capable of forming heterodimers with E-proteins and directly regulating the Scleraxis promoter, where Paraxis expression precedes Scleraxis in the somite (Wilson-Rawls et al., 2004). Mice that are homozygous for a Paraxis-null allele have somites that are segmentally and molecularly specified but ultimately fail to undergo MET and properly compartmentalize (Burgess etal., 1996). These mice die hours following birth due to complications attributed to axial skeleton and skeletal muscle patterning defects.

Several factors have been implicated in regulating Paraxis expression. Paraxis has been shown to be the target of $\beta$-Catenin signaling (Wagner et al., 2000; Schmidt et al., 2004; GeethaLoganathan et al., 2005; Linker et al., 2005). Frizzled7 transduces Wnt6 signaling, which is expressed in the ectoderm overlying the somites. Experiments utilizing a dominant-negative form of $\beta$-Catenin show that Paraxis is a mediator of $\beta$-Catenin signaling initiated by $W n t 6$ (Linker et al., 2005). Misexpression experiments show that both FoxC1 and FoxC2 are capable of inducing Paraxis while mutant mice display defects in dermomyotome patterning (Wilm et al., 2004). Snail2 over expression prevents cells from activating Paraxis, thus locking them in a mesenchymal state (Dale et al., 2006). Additionally, the Rho family GTPase Rac1 interacts with Paraxis and this interaction is necessary for inducing MET (Nakaya et al., 2004).

The most notable Paraxis transcriptional downstream targets are Pax family members. Detailed analysis of Paraxis; Mesp2 double-null embryos reveals that Paraxis directly regulates $P a x 3$, which lies upstream of $M y O D$, redundantly with Mesp1 (WilsonRawls et al., 1999; Takahashi et al., 2007). Furthermore, Paraxis directly regulates Pax 1 expression in the ventral sclerotome as revealed by analysis of Paraxis-null embryos (Wilson-Rawls et al., 2004; Takahashi et al., 2007). Also, the Iroquois class factor Mohawk is a downstream Paraxis target as Mohawk expression is downregulated within the somites in Paraxis-null embryos (Anderson et al., 2006).

\section{Scleraxis functions during mesoderm formation, ten- don formation and Sertoli cell development}

Scleraxis is observed throughout the early embryo at E6.0 making it one of the earliest Twist-family members to be expressed (Brown et al., 1999). High levels of the Scleraxis transcript then become detectable between E9.5 and E10.5 in the lateral region of the sclerotome and in mesenchymal cells of the limb buds and body wall (Cserjesi et al., 1995a). Scleraxis expression is detected in mesenchymal progenitors of the thyroid cartilage and hyroid bone, cranial mesenchyme, rib primordial, and pericardium by E11.0 (Cserjesi et al., 1995a). At E12.5 Scleraxis expression is also detectable in the diaphragm, connective tissue of the heart valves, and tongue (Cserjesi et al., 1995a; Lincoln etal., 2004). After E12.5 Scleraxisexpression declines in all tissue except for the diaphragm but becomes apparent in regions of future dense connective tissue such as lung bronchi, heart valves, and ligaments (Cserjesi et al., 1995a; Lincoln et al., 2004). Scleraxis expression becomes restricted to the dense connective tissue of ligaments and cartilage by E14.5 (Cserjesi et al., 1995a; Perez et al., 2003; Pryce et al., 2007). Though missed in the initial studies, Scleraxis is also expressed in the dense connective tissue comprising tendons of the trunk and limb at E14.5 (Schweitzer et al., 2001). Further studies have gone on to describe Scleraxis expression in tendon progenitors of the axial skeleton, which are derived from the syndetomal somitic compartment (Brent et al., 2003). Postnatally, Scleraxis is expressed in Sertoli cells following the onset of puberty in response to FSH (Muir et al., 2005).

The original Scleraxis-null mice fail to gastrulate and are ultimately unable to form mesoderm, suggesting an essential role for Scleraxis in early mesoderm formation (Brown et al., 1999). This observed lethality is largely due to the transcriptional effects of the neomycin-resistance cassette on neighboring genes, principally Bop1, a housekeeping gene that contains the entire Scleraxis gene within its third intron (Murchison et al., 2007). Using an FRTflanked neomycin cassette allowed for removal of neomyosin from the Scleraxis locus, where Scleraxis -null mice survived to term (Murchison et al., 2007). These Scleraxis null mice display severe disruption of tendon formation by E13.5 (Murchison et al., 2007). Scleraxis-null mice also have defects in testis development where mice that are homozygous for the null allele suffer from a range of spermatogenic cell defects (Muir et al., 2008).

Several molecules are thought to regulate Scleraxis expression. FGF signaling has been implicated in directly regulating Scleraxis (Kawa-uchi et al., 1998; Edom-Vovard et al., 2002). FGFB is expressed during limb tendon development and is sufficient to induce Scleraxis expression (Edom-Vovard et al., 2001). Pea3 and Erm, transcriptional effectors of FGF signaling, are necessary to induce Scleraxis transcription (Brent and Tabin, 2004). Within the Sclerotome, Scleraxis expression has also been shown to be supported by a MKP3-ERK-MAP feedback loop (Smith et al., 2005). BMP2, BMP4, and BMP7are expressed in a mutually exclusive domain from Scleraxis within the limb (Schweitzer et al., 2001). Using noggin soaked beads reveals an upregulation of Scleraxis in digits, supporting the idea that BMP's down regulate Scleraxis in the distal most parts of the limb (Schweitzer et al., 2001). In vitro studies confirm these results where application of $B M P 2$ or CDMP, a member of the BMP-family, were sufficient to down regulate Scleraxis and shift cells away from a mesodermal lineage and towards an osteogenic lineage (Liu et al., 1997a; Kramer et al., 2000; Yeh et al., 2005).

Downstream targets of Scleraxis also support a role in regulating tendon development. In vitro experiments show that over expression of Scleraxis supported differentiation towards a cartilage fate by increasing levels of the aggrecan gene, type II collagen, and osteopontin while repressing expression of genes implicated in osteoblast differentiation, namely type I collagen and alkaline phosphatase (Liu et al., 1997b). Expression of Scleraxis positively regulates Tenulomodulin, a late marker of tendon formation, in tendon fibroblasts (Shukunami et al., 2006). Heterodimers of Scleraxis and E47 have also been shown to regulate a type I collagen gene, COL1a1 in tendon fibroblast cells (Lejard et al., 2007). Thus far only Collagen 14 and Tenulomodulin have been demonstrated to be downstream of Scleraxis based on analysis of Scleraxis-null embryos (Murchison et al., 2007).

\section{Hand1 is required for proper cardiac morphogenesis and is essential for extra-embryonic and trophoblast- cell differentiation}

Hand1 was cloned from a yeast-2-hybrid screen using an E12 bait (Cserjesi et al., 1995b). Hand1 shares the highest degree of 
sequence identity with Hand2 and to a lesser extent with Twist1 and other family members (Srivastava et al., 1995). In situ hybridization shows Hand1 is expressed within the trophoblast cells of the ectoplacental cone prior to E7.5 with expression throughout the yolk sac, chorion \& extra embryonic mesoderm (Cserjesi et al., 1995b). Extra-embryonic expression of Hand1 is maintained throughout later stages of embryonic development (Cserjesi et al., 1995b).

In the embryo, Hand1 expression is first observed at embryonic day E7.5 in the lateral plate mesoderm that contributes to form the primitive heart tube (Srivastava et al., 1997). At E8.5 Hand1 is detected in the developing heart tube, pericardium, \& the distal regions of lateral mesoderm (Cserjesi et al., 1995a; Srivastava et al., 1995; Biben and Harvey, 1997). During rightward looping of the heart, Hand1 becomes restricted to the outer curvature of the myocardium contributing to the presumptive left ventricle, the septum transversum, and the pericardium where it persists thru E13.5 (Cserjesi et al., 1995b; Firulli et al., 1998; Thomas et al., 1998b). Hand1 expression continues to accumu- late throughout the lateral mesoderm where it persists in the developing gut distal to the duodenum (Morikawa and Cserjesi, 2004). Hand1 is also expressed throughout the umbilical and vitelline vein/artery by E9.5 (Firulli et al., 1998). Hand1 is also detected in the distal portions of the limb. At E11.5 it is expressed in the anteroventral domain of the limb bud where it is maintained thru E13.5 (Fernandez-Teran et al., 2003). Hand1 is expressed in adult-rodent and human hearts as well, where they are thought to play a role in preventing hypertrophy (Natarajan et al., 2001; Thattaliyath et al., 2002b).

Hand1 is also expressed within the cranial and cardiac neural crest cells occupying the medial pharyngeal arches and first appears at E9.5 as they begin to populate the outflow tract where they contribute to the smooth muscle lining the pulmonary artery (Cserjesi et al., 1995b; Barbosa etal., 2007; Vincentz et al., 2008). Hand1 continues to accumulate in structures derived from neural crest cells where by E10.5 it is detected in the sympathetic and splanchnic ganglia of the peripheral nervous system and the first and second aortic arch (Cserjesi et al., 1995b; Firulli et al., 1998;

TABLE 1

\section{TWIST-FAMILY bHLH PROTEIN EXPRESSION AND FUNCTION}

\begin{tabular}{|c|c|c|c|}
\hline Gene & Expression Pattern & Function & References \\
\hline twist & $\begin{array}{l}\text { Drosophila } \\
\text { Presumptive mesoderm } \\
\text { Mesodermal segments } \\
\text { Thorasic flight muscle progenitors }\end{array}$ & $\begin{array}{l}\text { Required for proper gastrulation. Twist homodimers specify mesoderm. } \\
\text { Twist-Daughterless heterodimers antagonize mesodermal differntiation, properly } \\
\text { patterning the mesoderm. Expression persisting in adult myoblasts maintains } \\
\text { an undifferentiated state. }\end{array}$ & $\begin{array}{l}\text { Thisse et al., 1987; } \\
\text { Baylies and Bate, 1996; Castanon et al., } 2001 \\
\text { Cripps and Olson, 1998; Bate et al., } 1991\end{array}$ \\
\hline Twist1 & \begin{tabular}{l}
\multicolumn{1}{c}{ Mouse } \\
extraembryonic mesoderm \\
alantois \\
head mesenchyme \& cranial sutures \\
pharyngeal arches \\
cephalic and thorasic neural crest \\
lateral mesoderm \\
distal limb bud mesenchyme
\end{tabular} & $\begin{array}{l}\text { Follows mesodermal induction. Required for proper cranial mesenchyme and } \\
\text { neural crest migration and distribution, directly affecting neural tube patterning } \\
\text { and cushioning. Patterns the limb and cranial suture where it functions } \\
\text { in a dimer dependent manner, regulated by dosage and phosphorylation. } \\
\text { by dosage and phosphorylation }\end{array}$ & $\begin{array}{l}\text { Wolf et al., 1991; Fuchtbauer, } 1995 \\
\text { Stoetzel et al., 1995; Chen and Behringer, } 1995 \\
\text { Gitelman et al., 1997; Bialek et al., } 2004 \\
\text { Firulli et al., 2005; Connerney et al., } 2006 \\
\text { Firulli et al., 2007; Connerney et al., } 2008\end{array}$ \\
\hline Twist2 & $\begin{array}{l}\text { Sclerotome, myotome, dermotome } \\
\text { branchial arches } \\
\text { limb bud mesenchyme } \\
\text { osteoblasts } \\
\text { dermis }\end{array}$ & $\begin{array}{l}\text { Essential for chondrogenesis, preventing differentiation of preosteoblasts. } \\
\text { Dermal expression is required for proper skin formation and wound healing. } \\
\text { Downstream of NF-kB directly repressing the cytokine p65 promoter } \\
\text { and antagonizing p53-dependent apoptosis. Helps in fatty acid synthesis. }\end{array}$ & $\begin{array}{l}\text { Li et al., 1995; Maestro et al., 1999; } \\
\text { Gong and Li, 2002; Sosic et al., , } 2003 \\
\text { Yu et al., 2003; Lee et al., } 2003\end{array}$ \\
\hline Paraxis & $\begin{array}{l}\text { caudal lateral \& parxial mesoderm } \\
\text { dermomyotome \& sclerotome } \\
\text { fore limb buds }\end{array}$ & $\begin{array}{l}\text { Maintains the epithelial characteristics of the somite acquired during } \\
\text { mesenchymal-to-epithelial transition (MET). Establishes proper axial skelton } \\
\text { and skeletal muscle patterning. }\end{array}$ & $\begin{array}{l}\text { Burgess et al., 1995; Burgess et al., } 1996 \\
\text { Wilson-Rawls et al., 1999; Locascio and Nieto, } 2001 \\
\text { Takahashi et al., } 2007\end{array}$ \\
\hline Scleraxis & $\begin{array}{l}\text { Sclerotome } \\
\text { Limb Bud } \\
\text { Cranial \& body wall mesenchyme } \\
\text { Pericardium \& Heart Valves } \\
\text { Ligaments \& Tendons }\end{array}$ & $\begin{array}{l}\text { Required for tendon formation, ligaments, connective tissue, the diaphragm, } \\
\text { and testis development. FGF signaling mediates Scleraxis signaling } \\
\text { while BMP signaling downregulates Sceraxis expression, shifting cells away from } \\
\text { a mesodermal towards an osteogenic lineage. }\end{array}$ & $\begin{array}{l}\text { Cserjesi et al. , 1995a; Brown et al., } 1999 \\
\text { Schweitzer et al., 2001; Brent et al., } 2003 \\
\text { Perez et al. , 2003; Lincoln et al., } 2004 \\
\text { Muir et al., 2005; Pryce et al., , } 2007 \\
\text { Murchison et al. , } 2007\end{array}$ \\
\hline Hand1 & $\begin{array}{l}\text { Extraembryonic Mesoderm } \\
\text { Alantois \& Trophoblast Cells } \\
\text { Pharyngeal Arches \& Mandible } \\
\text { Materal Mesoderm } \\
\text { Cranial \& Cardiac Neural Crest Cells } \\
\text { Sympathetic Ganglia } \\
\text { Left Ventricle, \& Outflow Tract } \\
\text { Pericardium } \\
\text { Limb buds }\end{array}$ & $\begin{array}{l}\text { Required for giant trophoblast cell development, vasculature, and mesoderm } \\
\text { formation in extraembryonic tissue. Establishes left ventricular and outflow tract } \\
\text { patterning. Phosphorylation regulates export from the nucleolus, activating } \\
\text { Hand1. }\end{array}$ & $\begin{array}{l}\text { Cserjesi et al., 1995b; Srivastava et al., } 1995 \\
\text { Firulli et al., 1998; Riley et al., } 1998 \\
\text { Fernandez-Teran et al., 2003; Firulli et al., } 2003 \\
\text { Morikawa and Cserjesi, 2004; McFadden et al., } 2005 \\
\text { Risebro et al., 2006; Martindill et al. , } 2007\end{array}$ \\
\hline Hand2 & $\begin{array}{l}\text { Decidua } \\
\text { Lateral Mesoderm } \\
\text { Right Ventricle \& Outflow Tract } \\
\text { Pharyngeal arches } \\
\text { Cranial \& Cardiac Neural Crest Cells } \\
\text { Sympathetic Ganglia } \\
\text { Adrenal Gland } \\
\text { Pericardium } \\
\text { Limb buds }\end{array}$ & $\begin{array}{l}\text { Patterns right ventricular and outflow tract. Regulates ANF in the heart. } \\
\text { Establishes cranial and limb morphogenesis. Required for noradrenergic } \\
\text { differentiation of the sympathetic nervous system. }\end{array}$ & $\begin{array}{l}\text { Srivastava et al., 1995; Srivastava et al., } 1997 \\
\text { McFadden et al., 2000; Charite et al., } 2000 \\
\text { Fernandez-Teran et al., } 2000 \\
\text { Ruest et al., 2003; Morikawa et al., } 2005 \\
\text { Hendershot et al., 2007; Morikawa et al., } 2007 \\
\text { Hendershot et al., 2008 }\end{array}$ \\
\hline
\end{tabular}


Howard et al., 1999; Morikawa and Cserjesi, 2004). At E12.5, Hand 1 is expressed in the sypatho/adrenal lineage as well as the mandible, which is derived from the pharyngeal arches (Cserjesi et al., 1995b; Firulli et al., 1998; Morikawa and Cserjesi, 2004). Hand1 mRNA-continues to persist in rudiments of neural crest derived tissues until E14.5 (Cserjesi et al., 1995b; Morikawa and Cserjesi, 2004).

Knock outs of Hand 1 die by E9.5 experiencing extra-embryonic and heart defects (Firulli et al., 1998; Riley et al., 1998; Morikawa and Cserjesi, 2004). Heart development of null mutants is arrested during formation of the heart tube where the caudal portion failed to fuse as shown by marker analysis (Firulli et al., 1998). Analysis of embryos homozygous for the Hand1-null allele showed that early myocardial markers such as Nkx2.5, Mef2C, Gata4, and MIc2awere unaffected (Firulli et al., 1998; Riley et al., 1998). Hand1-null embryoid bodies are capable of differentiating into cardiomyocytes (Riley et al., 2000) indicating that heart defects are not due to a failure of the myocardium to differentiate but due to improper patterning of the heart (Firulli et al., 1998). Tetraploid experiments using Rosa26 derived; Hand1-null ES cells are underrepresented in the left ventricular chamber but are capable of differentiating into cardiomyocytes in vitro indicating that Hand 1 is not necessarily essential for cardiomyocyte differentiation but is required for proper patterning of the left ventricle (Riley et al., 2000). Furthermore, the reduction of the left ventricle in mice with a conditional ablation of Hand1 in the heart substantiate this conclusion (McFadden et al., 2005), though more detailed analysis pairing the conditional Hand1-allele with a wider range of available Cre lines would be useful to support these findings.

Hand 1 is restricted to the outer wall of the ventricular chamber during rightward looping of the heart. An asymmetric expansion of cells in this outer curvature is tightly intertwined in the process, implicating a role for Hand1 in proliferation during heart remodeling. Misexpression of Hand 1 in the myocardium of both ventricular chambers resulted in an expansion of the outer curvature of both the left and the right ventricle (Togi et al., 2004). Over expression of Hand1 specifically in Hand1 expressing cells resulted in abnormal looping (Risebro et al., 2006). Though these hearts were accompanied by a failure of ventricular expansion, thorough analysis of these hearts revealed that Hand1 overexpression resulted in left-ventricular defects due to elevated myocyte density and reduced myocardial differentiation. Furthermore, cells over expressing Hand1 in Hand1-positive neural crest cells resulted in an elongated outflow tract due to continued proliferation and a failure to commit to differentiation (Risebro et al., 2006). The complimentarity of the phenotype between loss-offunction and gain-of-function mutations of Hand1 suggest a conserved role for Hand1 during heart morphogenesis. Additionally, they hint that proper Hand gene dosage is essential for proper development, which has been elucidated in further studies with Hand2 (McFadden et al., 2005; Barbosa et al., 2007).

Further analysis of Hand1-KO mice clearly shows that Hand1 is essential for the development of extra-embryonic tissue. Hand1 is expressed in all subtypes of trophoblast giant cells within the ectoplacental cone and chorion (Vasicek et al., 2003; Simmons et al., 2008). Hand1-null embryos have a dramatic down regulation of/within the ectoplacental cone. P/1 codes for a hormone and is expressed in the developing giant-trophoblast cells (Firulli et al.,
1998; Cross et al., 2002; Hughes et al., 2004). P/1 was detected in only a subset of giant cells outside of the ectoplacental cone in the placenta of Hand1-null embryos (Riley et al., 1998). The ectoplacental cone only contains an increased number of giant cell precursors, suggesting Hand1 plays a role during giant cell differentiation (Gardner et al., 1973). This conclusion gains support when considering that over-expression of Hand1 leads to an increase of $P / 1$ in giant cells (Cross et al., 1995) and Hand1 homozygous mutant trophoblast cells display deficiencies in differentiation and normal invasive behavior (Hemberger et al., 2004), illustrating the critical role for Hand1 in trophoblast cell development.

In regard to extra-embryonic tissues, Hand1 is also required for the formation of the extra-embryonic membrane, where it is expressed in the mesodermal compartment. Hand1-null embryos have abnormalities of the extra-embryonic vasculature following formation of the yolk sac by E7.5 (Firulli et al., 1998; Morikawa and Cserjesi, 2004). Analysis of Hand1-null embryos shows that the yolk sac maintains an immature vascular plexus and smooth muscle cells required for blood vessel support during vasculogenesis failed to undergo normal recruitment (Morikawa and Cserjesi, 2004).

Hand1 was initially thought to interact only with ubiquitously expressed E-proteins (Massari and Murre, 2000). Mammalian two-hybrid and pull-down assays confirmed that Hand1 could form homodimers as well as interact with other tissue restricted bHLH proteins, such as Hand2 (Firulli et al., 2000). Similar to Twist1, Hand1 was shown via EMSA's to inhibit MyoD/E12 DNAbinding (Firulli et al., 2000). Although the biological relevance of this is moot given Hand1 and MyoD are not co-expressed during development, it does speak to the evolutionary conservation within the Twist-family.

Dimer partner choice clearly infers differential regulation on Twist family proteins and this was first demonstrated with Hand1. The LIM domain protein FHL2 is capable of interacting with Hand1 in the nucleus and repressing function of Hand $1 / E 12$ heterodimers though it is incapable of effecting Hand1/Hand1 homodimer activity (Hill and Riley, 2004). Additionally, deletion of the basic DNA-binding domain does not inhibit Hand1's ability to induce limb polydactyly (McFadden et al., 2002). When considering this result carefully, the most likely mechanism to explain these findings would be actions as a dominant negative factor antagonizing the equilibrium of the bHLH dimer pool.

Hand1 phosphoregulation at Serine 107 and Threonine 109 modulates dimer partner specificity. Protein Kinase $A$ and C (PKA and $P K C$ ) which can phosphorylate these Hand1 residues while $\beta 56 \delta$-containing Protein Phosphatase 2A (PP2A) can specifically dephosphorylate these residues (Firulli et al., 2003). Phosphorylation of Hand1 increases during differentiation of trophoblast giant-cells and this is associated with a down regulation of $\beta 56 \delta$ (Firulli et al., 2003). Recently, it has been shown in trophoblast giant-cells that Hand1 is negatively regulated by interacting with I-mfa, which sequesters it to the nucleolus (Martindill et al., 2007; Martindill and Riley, 2008). Interestingly, the Hand1 hypophosphorylation mutant targets directly to the nucleolus where the protein is sequestered, preventing differentiation (Martindill et al., 2007; Martindill and Riley, 2008). Conversely a Hand1 phosphorylation mimic resides solely within the nucleus and expression drives trophoblast differentiation (Martindill et al., 
2007; Martindill and Riley, 2008). This data demonstrates that phosphoregulation modulates dimer choice in at least two ways. First by directly effecting protein affinity and second my dictating cell localization.

To date, upstream regulators and downstream transcriptional targets of Hand1 have been difficult to ascertain. Hand1 in vitro can activate the promoter of cardiac atrial natriuretic factor, implicating it as a potential target of Hand1 (Morin et al., 2005). Hand1 is co expressed in the heart with Thymosin $\beta 4$, which is downregulated in Hand1-null embryoid bodies, as well as cytostatin $C$, and $\alpha C A$, which are found to be up regulated (Smart et al., 2002). Ectopic expression of Tbx5 results in enhanced Hand1 expression while simultaneously suppressing Hand2, suggesting that Tbx5can impart left ventricular identity upon Hand1 expressing cells found throughout this region (Takeuchi et al., 2003). Regarding upstream regulation, Nkx2.5 knockout mice, which regulates expression of a number of cardiac specific genes, results in a severe reduction of Hand1 in the heart, implicating that Nkx2.5 may be upstream of Hand1 (Tanaka et al., 1999).

\section{Hand2 is required during development of the heart, limbs, autonomic nervous system, \& other neural crest derived structures}

Hand2 (formerly dHand) was identified in a low stringency cDNA library screen using a Hand1 bHLH domain probe (Srivastava et al., 1995). In the chick, Hand2 is first detected in the lateral mesoderm, and cardiac crescent; later it is expressed throughout the developing heart tube (Srivastava et al., 1995). In the mouse, Hand2 is first expressed at E7.5 in the maternally derived decidua and is first detected in the embryo at E7.75 in the lateral mesoderm that forms the cardiac crescent and is maintained throughout the linear heart tube to E8.0 (Srivastava et al., 1997). At the onset of cardiac looping, Hand2 cardiac expression subsequently restricts to the forming right ventricle and outflow tract down regulating within the left ventricle, which expresses Hand1 (Overbeek, 1997; Srivastava et al., 1997; Firulli et al., 1998; McFadden et al., 2000). Hand2 is also expressed in the pharyngeal arches and neural crest cells where they give rise to craniofacial structures, outflow tract, the sympathetic nervous system, extra-adrenal chromaffin cells, as well as the posterior portion of the limb buds, (Gestblom et al., 1999; Charite et al., 2000; Ruest et al., 2003).

Hand2-null embryos die by E9.5 suffering with severe morphological deficiencies in the heart as they have only a single left ventricle (Srivastava et al., 1997). Hand2-null embryos undergo apoptosis in the region of the forming right ventricle (bulbous cordis) and results in a down regulation of ventricular markers such as $/ r \times 4$, suggesting a role for maintenance of the right ventricle progenitors and supporting ventricular expansion (Bruneau et al., 2000; McFadden et al., 2000; Yamagishi et al., 2001). This role for Hand2 is further supported by evidence that a conditional deletion of Gata4 in the heart, which has been shown to directly regulate a ventricular enhancer element of Hand2, results in right ventricular hypoplasia (McFadden etal., 2000; Zeisberg et al., 2005). Over expression of Hand2 in the ventricles results in outward expansion of the ventricular chamber as well as an absence of the interventricular septum, which is replaced by an expanded trabecular domain, further establishing a role for Hand2 in supporting ventriculogenesis (Togi et al., 2006). In mice that have a homozygous-null allele for $m$-Bop, the histone deacetylasedependent transcriptional repressor, Hand2 expression is down regulated and there is an associated disruption of ventricular myocardial development (Gottlieb et al., 2002). Data that may partially explain the Hand sided expression can be seen in studies of Tbx5 (Takeuchi et al., 2003). Tbx5 can suppress Hand2 concurrent with upregulation of Hand1.

Hand2 has been shown to directly regulate Anf. In Hand2null mice, $A n f$ is downregulated while a Hand2-heterodimer has been shown to trans-activates the Anfpromoter (Thattaliyath et al., 2002a). Additionally, Hand2 cooperates with Mef2c to activate both Anf and $\alpha$ MHC (Zang et al., 2004a, Zang et al., 2004b). Moreover, Hand2 can synergize with Gata4 to activate Anf as well, revealing a multifunctional role for Hand2 in Anf regulation (Dai et al., 2002).

Recently, it has been demonstrated that Hand2 is the direct target of microRNAs. A heart conditional knock out of Dicer, an enzyme required for processing of precursor microRNAs, results in the upregulation of Hand2 (Zhao et al., 2007). miR-1, a cardiac and skeletal muscle-restricted microRNA, is negatively affected in the Dicer knockouts. miR-1 over expression leads to a reduction in ventricular myocardium and is also capable of directly targeting Hand2 (Zhao et al., 2005).

Hand2 is also expressed throughout the cephalic neural crest mesenchyme of the first and second pharyngeal arches and plays a role in facial morphogenesis, where expression is directed by a Hand2 enhancer element complete and separate from the ventricular heart enhancer (McFadden et al., 2000; Ruest et al., 2003; Yanagisawa et al., 2003). Endothelin-1 $(E d n 1)$, which is expressed in the epithelial layer of the branchial arches, regulates Hand2 and is downregulated in the branchial arches in Edn1-null mice (Thomas et al., 1998a, Ivey et al., 2003; Li and Li, 2006). The Edn1 downstream effectors $D / \times 5 \& D / \times 6$ directly regulate Hand2transcription via a DIx ciselement located within the Hand2 branchial arch enhancer (Charite et al., 2001; Fukuhara et al., 2004). Targeted deletion of the Hand2 branchial arch enhancer confirms that Hand2 is required for craniofacial development as mutants exhibit craniofacial abnormalities that include cleft palate, mandibular hypoplasia, as well as a range of cartilage malformations (Yanagisawa et al., 2003). A small domain of Hand2expressing cells in the distal most portion of the pharyngeal arches appears to be $E d n 1$ independent and is instead thought to be regulated by GATA3 (Ruest et al., 2004). A conditional neural crest cell deletion of Mef2c shows that Mef2clikely mediates Endothelin signaling in the pharyngeal arches and is required for $D / x 5 \& 6$ and Hand2(Verzi et al., 2007). Pharyngeal arch mesenchyme undergoes apoptosis in Hand2-null embryos by E9.5; however cell death is partially rescued when mice are also null for Apaf1 (Thomas et al., 1998a, Aiyer et al., 2005).

Hand2 is necessary for limb morphogenesis. Hand2 is expressed in the posterior portion of the developing limb buds in the signaling region called the zone of polarizing activity (ZPA) (Charite et al., 2000; Fernandez-Teran et al., 2000). It has been implicated that retinoic acid signaling first establishes Hand2 in the ZPA (Mic et al., 2004). Hand2 can up regulate expression of Sonic Hedge Hog (Shh) in the ZPA and expression of Shhup 
regulates expression of Hand2. Over expression of Hand2 in the limb buds results in polydactyly associated with expanded Shhexpression, which results in ectopic ZPA formation (Charite et al., 2000; Fernandez-Teran et al., 2000; McFadden et al., 2002) while Hand2-null embryos lack any Shh expression domain (Charite et al., 2000). Hand2also up regulates the BMP antagonist Gremlin, which acts to maintain an Shh/FGF feedback loop that maintains the ZPA (Zuniga and Zeller, 1999; McFadden et al., 2002). The Shh repressor Gli3 helps to restrict Hand2 expression to the ZPA, which in turn feedbacks to regulate Gli3, allowing Shh signaling (te Welscher et al., 2002a; te Welscher et al., 2002b; Liu et al., 2005a). Additional factors that potentially regulate Hand2 in the limb are $T b \times 3$ and Hoxd13 due to their co expression Twist1 (Rallis et al., 2005; Salsi et al., 2008).

Hand2 is expressed in multiple derivatives of neural crest cells, including the peripheral nervous system. Specifically, Hand2 has been implicated in specification and maintenance of the noradrenergic phenotype of the sympathetic nervous system and chromaffin cells of the sympathoadrenal lineage development (Huber et al., 2002; Xu et al., 2003). Ectopic expression of Hand2 is capable of activating the noradrenergic program (Howard et al., 1999; Morikawa et al., 2005). BMP's have been implicated in activating the noradrenergic phenotype and several of the transcription factors regulating sympathetic differentiation, including Hand2 (Howard et al., 2000; Muller and Rohrer, 2002; Liu et al., 2005b). Unlike other transcription factors expressed during sympathetic neurogenesis that are responsive to BMP's which include Phox2a, Phox2b, and Mash1, only Hand2 is exclusive to noradrenergic differentiation. Cilliary neurons lacking Hand2 expression become cholinergic in response to BMP (Muller and Rohrer, 2002). Additionally, mesenchephalic neural crest cells that are Hand2negative cannot differentiate into catecholaminergic neurons (Lee et al., 2005).

These studies suggest a role for Hand2 specifying and maintaining the noradrenergic phenotype during catecholaminergic differentiation. Additional evidence to support this hypothesis is that Hand2 directly transactivates Dopamine $\beta$-Hydroxylase (DBH) in conjunction with Phox2a (Rychlik et al., 2003; Xu et al., 2003). Conditional knockouts of Hand2 in neural crest cells reveals that sympathetic precursors differentiate into neurons but fail to express noradrenergic biosynthesis enzymes, such as $D B H$, further suggesting a role in the determination of the catecholaminergic phenotype (Morikawa et al., 2007; Hendershot et al., 2008). In the enteric nervous system, gain-of-function of Hand2 results in an overall increase of neurogenesis, suggesting it may have the potential to drive the noradrenergic phenotype; however, Hand2 loss of function suggests that Hand2neural crest migrate properly and express neurogenic markers but fail to terminally differentiate, again suggesting a role for Hand2 in specification and maintenance of the noradrenergic phenotype (D'Autreaux et al., 2007; Hendershot et al., 2007). In Zebrafish, there is only a single hand gene most identical to Hand2. A mutation of Hand2, called Hands off, shows that sympathetic precursors migrate properly and undergo proper neurogenesis, but ultimately fail to express noradrenergic genes indicative of terminal differentiation of catecholaminergic neurons (Lucas et al., 2006).
As with all Twist-family bHLH's, Hand2 is capable of forming heterodimers with $\mathrm{E}$ proteins to regulate transcription (Dai and Cserjesi, 2002). Though E-proteins are ubiquitously expressed in embryonic tissue, they are expressed at lower levels in the heart, suggesting that Hand2 potentially dimerizes with other $\mathrm{bHLH}$ proteins or other factors to regulate development in heart tissue (Murakami et al., 2004). Among these potential dimer partners, it has been shown that Hand2can heterodimerize with Hand1 and potentially acts as an inhibitor, imparting a multifunctional role on Handfactors (Firulli et al., 2000). GATA4 has also been shown to synergize with Hand2 to activate Anf through a direct interaction with P300 (Dai et al., 2002). The ability of Hand2 to transactivate is enhanced through stabilization when bound to DNA by JAB1 (Dai et al., 2004).

Phosphoregulation also regulates dimerization of Hand2. As previously discussed in Twist1, phosphorylation alters the dimerization preference of Hand2, mediated by PKA, and directly influences the antagonistic relationship with Twist1 (Firulli et al., 2003; Firulli et al., 2005). BMP's regulate Hand2 via induction of PKA, which phosphorylates the conserved helix 1 threonine and serine promoting noradrenergic differentiation from a specified cell type (Liu et al., 2005b).

\section{Summary}

Twist-family bHLH proteins share a partially overlapping and expansive domain of expression throughout many stages of embryonic development. However, as illustrated in this review, each member plays a unique role during gestation mostly due to tight, specific regulation of each gene and subsequently protein. A network of transcriptional regulation, including chromatin conformation, tissue-restricted enhancer elements, and micro-RNA regulation, ensures tightly controlled spatial and temporal expression and ultimately sets the potential bHLH dimer pool in each cell. bHLH proteins function by binding $\mathrm{E}$ boxes following dimerization with other bHLH proteins. Twistfamily members exhibit a wide range of potential bHLH dimers as they are capable of forming a multitude of heterodimers and homodimers, creating an environment for dynamic and complex regulation due to potential alterations in function. Recently it has been established that a phospho-regulatory circuit shared in Twist-family members due to conserved serine and threonine residues dynamically regulates posttranslational modification, altering protein behavior and function. Though many of these proteins share significant regulatory mechanisms, these mechanisms often times employ unique functional characteristics to each protein. For instance, phosphorylation regulates Twist1 and Hand1, however the mechanism for each appears different as Twist 1 appears to undergo an alteration in preference for its dimer partner with other bHLH proteins while Hand1 undergoes export from the nucleolus. Therefore, it is likely that a multitude of information regarding regulation of Twist-family members, particularly post translationally has yet to be explored.

While systemic knockouts of all Twist-family members have been completed, conditional knockout analysis is not altogether complete or in some cases has yet to be established. Comprehensive analysis of conditional knockouts for all Twist family members will serve particularly useful given their overwhelming broad and overlapping spatial and temporal expres- 
sion. Additionally, future construction of mouse lines engineered to characterize specific bHLH dimer function will serve useful to pinpoint the in vivo function for each Twist-family member in different developmental system.

\section{References}

ACLOQUE, H., THIERY, J.P. and NIETO, M.A. (2008). The physiology and pathology of the EMT. Meeting on the Epithelial-Mesenchymal Transition. EMBO Rep 9: 322-326.

AIYER, A.R., HONARPOUR, N., HERZ, J. and SRIVASTAVA, D. (2005). Loss of Apaf-1 leads to partial rescue of the HAND2-null phenotype. Dev Bio/278: 155162.

ANDERSON, D.M., ARREDONDO, J., HAHN, K., VALENTE, G., MARTIN, J.F., WILSON-RAWLS, J. and RAWLS, A. (2006). Mohawk is a novel homeobox gene expressed in the developing mouse embryo. Dev Dyn 235: 792-801.

ASLAKSON, C.J. and MILLER, F.R. (1992). Selective events in the metastatic process defined by analysis of the sequential dissemination of subpopulations of a mouse mammary tumor. Cancer Res 52: 1399-1405.

BARBOSA, A.C., FUNATO, N., CHAPMAN, S., MCKEE, M.D., RICHARDSON, J.A., OLSON, E.N. and YANAGISAWA, H. (2007). Hand transcription factors cooperatively regulate development of the distal midline mesenchyme. Dev Biol 310: 154-168.

BATE, M. and ARIAS, A.M. (1991). The embryonic origin of imaginal discs in Drosophila. Development 112: 755-761.

BATE, M., RUSHTON, E. and CURRIE, D.A. (1991). Cells with persistent twist expression are the embryonic precursors of adult muscles in Drosophila. Development 113: 79-89.

BAYLIES, M.K. and BATE, M. (1996). twist: a myogenic switch in Drosophila. Science 272: 1481-1484.

BIALEK, P., KERN, B., YANG, X., SCHROCK, M., SOSIC, D., HONG, N., WU, H., YU, K., ORNITZ, D.M., OLSON, E.N. et al. (2004). A twist code determines the onset of osteoblast differentiation. Dev Cel/6: 423-435.

BIBEN, C. and HARVEY, R.P. (1997). Homeodomain factor Nkx2-5 controls left/ right asymmetric expression of bHLH gene eHand during murine heart development. Genes Dev 11: 1357-1369.

BOURGEOIS, P., BOLCATO-BELLEMIN, A.L., DANSE, J.M., BLOCH-ZUPAN, A., YOSHIBA, K., STOETZEL, C. and PERRIN-SCHMITT, F. (1998). The variable expressivity and incomplete penetrance of the twist-null heterozygous mouse phenotype resemble those of human Saethre-Chotzen syndrome. Hum Mol Genet 7: 945-957.

BRENT, A.E., SCHWEITZER, R. and TABIN, C.J. (2003). A somitic compartment of tendon progenitors. Cel/113: 235-248.

BRENT, A.E. and TABIN, C.J. (2004). FGF acts directly on the somitic tendon progenitors through the Ets transcription factors Pea3 and Erm to regulate scleraxis expression. Development 131: 3885-3896.

BROWN, D., WAGNER, D., LI, X., RICHARDSON, J.A. and OLSON, E.N. (1999). Dual role of the basic helix-loop-helix transcription factor scleraxis in mesoderm formation and chondrogenesis during mouse embryogenesis. Development 126: 4317-4329.

BRUNEAU, B.G., BAO, Z.Z., TANAKA, M., SCHOTT, J.J., IZUMO, S., CEPKO, C.L., SEIDMAN, J.G. and SEIDMAN, C.E. (2000). Cardiac expression of the ventricle-specific homeobox gene Irx4 is modulated by Nkx2-5 and dHand. Dev Bio/217: 266-277.

BURGESS, R., CSERJESI, P., LIGON, K.L. and OLSON, E.N. (1995). Paraxis: a basic helix-loop-helix protein expressed in paraxial mesoderm and developing somites. Dev Bio/168: 296-306.

BURGESS, R., RAWLS, A., BROWN, D., BRADLEY, A. and OLSON, E.N. (1996). Requirement of the paraxis gene for somite formation and musculoskeletal patterning. Nature 384: 570-573.

CASTANON, I. and BAYLIES, M.K. (2002). A Twist in fate: evolutionary comparison of Twist structure and function. Gene 287: 11-22.

CASTANON, I., VON STETINA, S., KASS, J. and BAYLIES, M.K. (2001). Dimerization partners determine the activity of the Twist bHLH protein during Drosophila mesoderm development. Development 128: 3145-3159.
CHARITE, J., MCFADDEN, D.G., MERLO, G., LEVI, G., CLOUTHIER, D.E., YANAGISAWA, M., RICHARDSON, J.A. and OLSON, E.N. (2001). Role of DIx6 in regulation of an endothelin-1-dependent, dHAND branchial arch enhancer. Genes Dev 15: 3039-3049.

CHARITE, J., MCFADDEN, D.G. and OLSON, E.N. (2000). The bHLH transcription factor dHAND controls Sonic hedgehog expression and establishment of the zone of polarizing activity during limb development. Development 127: 24612470.

CHEN, Y.T., AKINWUNMI, P.O., DENG, J.M., TAM, O.H. and BEHRINGER, R.R. (2007). Generation of a Twist1 conditional null allele in the mouse. Genesis 45: 588-592.

CHEN, Z.F. and BEHRINGER, R.R. (1995). twist is required in head mesenchyme for cranial neural tube morphogenesis. Genes Dev 9: 686-699.

CONNERNEY, J., ANDREEVA, V., LESHEM, Y., MERCADO, M.A., DOWELL, K., YANG, X., LINDNER, V., FRIESEL, R.E. and SPICER, D.B. (2008). Twist1 homodimers enhance FGF responsiveness of the cranial sutures and promote suture closure. Dev Bio/318: 323-334.

CONNERNEY, J., ANDREEVA, V., LESHEM, Y., MUENTENER, C., MERCADO, M.A. and SPICER, D.B. (2006). Twist1 dimer selection regulates cranial suture patterning and fusion. Dev Dyn 235: 1345-1357.

CRIPPS, R.M., BLACK, B.L., ZHAO, B., LIEN, C.L., SCHULZ, R.A. and OLSON, E.N. (1998). The myogenic regulatory gene Mef2 is a direct target for transcriptional activation by Twist during Drosophila myogenesis. Genes Dev 12: 422434.

CRIPPS, R.M. and OLSON, E.N. (1998). Twist is required for muscle template splitting during adult Drosophila myogenesis. Dev Bio/203: 106-115.

CRONMILLER, C. and CUMMINGS, C.A. (1993). The daughterless gene product in Drosophila is a nuclear protein that is broadly expressed throughout the organism during development. Mech Dev 42: 159-169.

CROSS, J.C., ANSON-CARTWRIGHT, L. and SCOTT, I.C. (2002). Transcription factors underlying the development and endocrine functions of the placenta. Recent Prog Horm Res 57: 221-234.

CROSS, J.C., FLANNERY, M.L., BLANAR, M.A., STEINGRIMSSON, E., JENKINS, N.A., COPELAND, N.G., RUTTER, W.J. and WERB, Z. (1995). Hxt encodes a basic helix-loop-helix transcription factor that regulates trophoblast cell development. Development 121: 2513-2523.

CSERJESI, P., BROWN, D., LIGON, K.L., LYONS, G.E., COPELAND, N.G., GILBERT, D.J., JENKINS, N.A. and OLSON, E.N. (1995a). Scleraxis: a basic helix-loop-helix protein that prefigures skeletal formation during mouse embryogenesis. Development 121: 1099-1110.

CSERJESI, P., BROWN, D., LYONS, G.E. and OLSON, E.N. (1995b). Expression of the novel basic helix-loop-helix gene eHAND in neural crest derivatives and extraembryonic membranes during mouse development. Dev Bio/ 170: 664678.

CURRIE, D.A. and BATE, M. (1991). The development of adult abdominal muscles in Drosophila: myoblasts express twist and are associated with nerves. Deve/opment 113: 91-102.

D'AUTREAUX, F., MORIKAWA, Y., CSERJESI, P. and GERSHON, M.D. (2007). Hand2 is necessary for terminal differentiation of enteric neurons from crestderived precursors but not for their migration into the gut or for formation of glia. Development 134: 2237-2249.

DAI, Y.S. and CSERJESI, P. (2002). The basic helix-loop-helix factor, HAND2, functions as a transcriptional activator by binding to $\mathrm{E}$-boxes as a heterodimer. $J$ Biol Chem 277: 12604-12612.

DAI, Y.S., CSERJESI, P., MARKHAM, B.E. and MOLKENTIN, J.D. (2002). The transcription factors GATA4 and dHAND physically interact to synergistically activate cardiac gene expression through a p300-dependent mechanism. J Biol Chem 277: 24390-24398.

DAI, Y.S., HAO, J., BONIN, C., MORIKAWA, Y. and CSERJESI, P. (2004). JAB1 enhances HAND2 transcriptional activity by regulating HAND2 DNA binding. $J$ Neurosci Res 76: 613-622.

DALE, J.K., MALAPERT, P., CHAL, J., VILHAIS-NETO, G., MAROTO, M., JOHNSON, T., JAYASINGHE, S., TRAINOR, P., HERRMANN, B. and POURQUIE, O. (2006). Oscillations of the snail genes in the presomitic mesoderm coordinate segmental patterning and morphogenesis in vertebrate somitogenesis. Dev Cel/10: 355-366. 
EDOM-VOVARD, F., BONNIN, M. and DUPREZ, D. (2001). Fgf8 transcripts are located in tendons during embryonic chick limb development. Mech Dev108: 203-206.

EDOM-VOVARD, F., SCHULER, B., BONNIN, M.A., TEILLET, M.A. and DUPREZ, D. (2002). Fgf4 positively regulates scleraxis and tenascin expression in chick limb tendons. Dev Bio/247: 351-366.

FERNANDEZ-TERAN, M., PIEDRA, M.E., KATHIRIYA, I.S., SRIVASTAVA, D., RODRIGUEZ-REY, J.C. and ROS, M.A. (2000). Role of dHAND in the anteriorposterior polarization of the limb bud: implications for the Sonic hedgehog pathway. Development 127: 2133-2142.

FERNANDEZ-TERAN, M., PIEDRA, M.E., RODRIGUEZ-REY, J.C., TALAMILLO, A. and ROS, M.A. (2003). Expression and regulation of eHAND during limb development. Dev Dyn 226: 690-701.

FIRULLI, A.B., MCFADDEN, D.G., LIN, Q., SRIVASTAVA, D. and OLSON, E.N. (1998). Heart and extra-embryonic mesodermal defects in mouse embryos lacking the bHLH transcription factor Hand1. Nat Genet 18: 266-270.

FIRULLI, B.A., HADZIC, D.B., MCDAID, J.R. and FIRULLI, A.B. (2000). The basic helix-loop-helix transcription factors dHAND and eHAND exhibit dimerization characteristics that suggest complex regulation of function. $J$ Biol Chem 275 : 33567-33573.

FIRULLI, B.A., HOWARD, M.J., MCDAID, J.R., MCILREAVEY, L., DIONNE, K.M., CENTONZE, V.E., CSERJESI, P., VIRSHUP, D.M. and FIRULLI, A.B. (2003). PKA, PKC, and the protein phosphatase 2A influence HAND factor function: a mechanism for tissue-specific transcriptional regulation. Mol Cel/ 12: 12251237.

FIRULLI, B.A., KRAWCHUK, D., CENTONZE, V.E., VARGESSON, N., VIRSHUP, D.M., CONWAY, S.J., CSERJESI, P., LAUFER, E. and FIRULLI, A.B. (2005). Altered Twist1 and Hand2 dimerization is associated with Saethre-Chotzen syndrome and limb abnormalities. Nat Genet 37: 373-381.

FIRULLI, B.A., REDICK, B.A., CONWAY, S.J. and FIRULLI, A.B. (2007). Mutations within helix I of Twist1 result in distinct limb defects and variation of DNA binding affinities. J Biol Chem 282: 27536-27546.

FUCHTBAUER, E.M. (1995). Expression of M-twist during postimplantation development of the mouse. Dev Dyn 204: 316-322.

FUKUHARA, S., KURIHARA, Y., ARIMA, Y., YAMADA, N. and KURIHARA, H. (2004). Temporal requirement of signaling cascade involving endothelin-1/ endothelin receptor type A in branchial arch development. Mech Dev121: 12231233.

GANGULY, A., JIANG, J. and IP, Y.T. (2005). Drosophila WntD is a target and an inhibitor of the Dorsal/Twist/Snail network in the gastrulating embryo. Development 132: 3419-3429.

GARDNER, R.L., PAPAIOANNOU, V.E. and BARTON, S.C. (1973). Origin of the ectoplacental cone and secondary giant cells in mouse blastocysts reconstituted from isolated trophoblast and inner cell mass. J Embryol Exp Morpho/30: 561-572.

GEETHA-LOGANATHAN, P., NIMMAGADDA, S., PROLS, F., PATEL, K., SCAAL, M., HUANG, R. and CHRIST, B. (2005). Ectodermal Wnt-6 promotes Myf5dependent avian limb myogenesis. Dev Bio/288: 221-233.

GESTBLOM, C., GRYNFELD, A., ORA, I., ORTOFT, E., LARSSON, C., AXELSON, H., SANDSTEDT, B., CSERJESI, P., OLSON, E.N. and PAHLMAN, S. (1999). The basic helix-loop-helix transcription factor dHAND, a marker gene for the developing human sympathetic nervous system, is expressed in both high- and low-stage neuroblastomas. Lab Invest 79: 67-79.

GIEBEL, B., STUTTEM, I., HINZ, U. and CAMPOS-ORTEGA, J.A. (1997). Lethal of scute requires overexpression of daughterless to elicit ectopic neuronal development during embryogenesis in Drosophila. Mech Dev63: 75-87.

GONG, X.Q. and LI, L. (2002). Dermo-1, a multifunctional basic helix-loop-helix protein, represses MyoD transactivation via the HLH domain, MEF2 interaction, and chromatin deacetylation. J Biol Chem 277: 12310-12317.

GOTTLIEB, P.D., PIERCE, S.A., SIMS, R.J., YAMAGISHI, H., WEIHE, E.K., HARRISS, J.V., MAIKA, S.D., KUZIEL, W.A., KING, H.L., OLSON, E.N. et al. (2002). Bop encodes a muscle-restricted protein containing MYND and SET domains and is essential for cardiac differentiation and morphogenesis. Nat Genet 31: 25-32

GRIFONE, R., DEMIGNON, J., HOUBRON, C., SOUIL, E., NIRO, C., SELLER, M.J., HAMARD, G. and MAIRE, P. (2005). Six1 and Six4 homeoproteins are required for $\mathrm{Pax} 3$ and Mrf expression during myogenesis in the mouse embryo. Development 132: 2235-2249.

GRIPP, K.W., ZACKAI, E.H. and STOLLE, C.A. (2000). Mutations in the human TWIST gene. Human Mutation 15: 150-155.

HAMAMORI, Y., WU, H.Y., SARTORELLI, V. and KEDES, L. (1997). The basic domain of myogenic basic helix-loop-helix (bHLH) proteins is the novel target for direct inhibition by another bHLH protein, Twist. Mol Cel/ Bio/17: 6563-6573.

HEBROK, M., WERTZ, K. and FUCHTBAUER, E.M. (1994). M-twist is an inhibitor of muscle differentiation. Dev Bio/165: 537-544.

HEMBERGER, M., HUGHES, M. and CROSS, J.C. (2004). Trophoblast stem cells differentiate in vitro into invasive trophoblast giant cells. Dev Bio/271: 362-31.

HENDERSHOT, T.J., LIU, H., CLOUTHIER, D.E., SHEPHERD, I.T., COPPOLA, E., STUDER, M., FIRULLI, A.B., PITTMAN, D.L. and HOWARD, M.J. (2008). Conditional deletion of Hand2 reveals critical functions in neurogenesis and cel type-specific gene expression for development of neural crest-derived noradrenergic sympathetic ganglion neurons. Dev Biol. 319: 179-191.

HENDERSHOT, T.J., LIU, H., SARKAR, A.A., GIOVANNUCCI, D.R., CLOUTHIER, D.E., ABE, M. and HOWARD, M.J. (2007). Expression of Hand2 is sufficient for neurogenesis and cell type-specific gene expression in the enteric nervous system. Dev Dyn 236: 93-105

HILL, A.A. and RILEY, P.R. (2004). Differential regulation of Hand1 homodimer and Hand1-E12 heterodimer activity by the cofactor FHL2. Mol Ce// Bio/24: 98359847.

HOEK, K., RIMM, D.L., WILLIAMS, K.R., ZHAO, H., ARIYAN, S., LIN, A., KLUGER H.M., BERGER, A.J., CHENG, E., TROMBETTA, E.S. et al. (2004). Expression Profiling Reveals Novel Pathways In The Transformation Of Melanocytes To Melanomas. Cancer Research 64: 5270-5282.

HOWARD, M., FOSTER, D.N. and CSERJESI, P. (1999). Expression of HAND gene products may be sufficient for the differentiation of avian neural crestderived cells into catecholaminergic neurons in culture. Dev Bio/215: 62-77.

HOWARD, M.J., STANKE, M., SCHNEIDER, C., WU, X. and ROHRER, H. (2000) The transcription factor dHAND is a downstream effector of BMPs in sympathetic neuron specification. Development 127: 4073-4081.

HUBER, K., BRUHL, B., GUILLEMOT, F., OLSON, E.N., ERNSBERGER, U. and UNSICKER, K. (2002). Development of chromaffin cells depends on MASH1 function. Development 129: 4729-4738.

HUGHES, M., DOBRIC, N., SCOTT, I.C., SU, L., STAROVIC, M., ST-PIERRE, B., EGAN, S.E., KINGDOM, J.C. and CROSS, J.C. (2004). The Hand1, Stra13 and Gcm 1 transcription factors override FGF signaling to promote terminal differentiation of trophoblast stem cells. Dev Bio/271: 26-37

IP, Y.T. and GRIDLEY, T. (2002). Cell movements during gastrulation: snai dependent and independent pathways. Curr Opin Genet Dev 12: 423-429.

ISHII, M., MERRILL, A.E., CHAN, Y.S., GITELMAN, I., RICE, D.P., SUCOV, H.M. and MAXSON, R.E., JR. (2003). Msx2 and Twist cooperatively control the development of the neural crest-derived skeletogenic mesenchyme of the murine skull vault. Development 130: 6131-6142.

IVEY, K., TYSON, B., UKIDWE, P., MCFADDEN, D.G., LEVI, G., OLSON, E.N. SRIVASTAVA, D. and WILKIE, T.M. (2003). Galphaq and Galpha11 proteins mediate endothelin-1 signaling in neural crest-derived pharyngeal arch mesenchyme. Dev Bio/255: 230-237.

IYER, N.V., LEUNG, S.W. and SEMENZA, G.L. (1998). The human hypoxiainducible factor 1 alpha gene: HIF1A structure and evolutionary conservation. Genomics 52: 159-165

JABS, E.W. (2004). TWIST and the Saethre-Chotzen Sydrome. In Molecular Basis of Inborn Errors of Development, (ed. EPSTEIN, C.ERICKSON, R. and SYNSHAW-BORIS, A.). Oxford University Press, New York, pp.401-409.

JAFAR-NEJAD, H., TIEN, A.C., ACAR, M. and BELLEN, H.J. (2006). Senseless and Daughterless confer neuronal identity to epithelial cells in the Drosophila wing margin. Development 133: 1683-1692.

JOHNSON, D., HORSLEY, S.W., MOLONEY, D.M., OLDRIDGE, M., TWIGG, S.R., WALSH, S., BARROW, M., NJOLSTAD, P.R., KUNZ, J., ASHWORTH, G.J. et al. (1998). A comprehensive screen for TWIST mutations in patients with craniosynostosis identifies a new microdeletion syndrome of chromosome band 7p21.1. Am J Hum Genet 63: 1282-1293.

JOHNSON, D., ISEKI, S., WILKIE, A.O. and MORRISS-KAY, G.M. (2000). Expression patterns of Twist and Fgfr1, -2 and -3 in the developing mouse coronal 
suture suggest a key role for twist in suture initiation and biogenesis. Mech Dev 91: 341-345.

KAWA-UCHI, T., NIFUJI, A., MATAGA, N., OLSON, E.N., BONAVENTURE, J., SHINOMIYA, K., LIU, Y. and NODA, M. (1998). Fibroblast growth factor downregulates expression of a basic helix-loop-helix-type transcription factor, scleraxis, in a chondrocyte-like cell line, TC6. J Cell Biochem 70: 468-477.

KOLSCH, V., SEHER, T., FERNANDEZ-BALLESTER, G.J., SERRANO, L. and LEPTIN, M. (2007). Control of Drosophila gastrulation by apical localization of adherens junctions and RhoGEF2. Science 315: 384-386.

KRAMER, J., HEGERT, C., GUAN, K., WOBUS, A.M., MULLER, P.K. and ROHWEDEL, J. (2000). Embryonic stem cell-derived chondrogenic differentiation in vitro: activation by BMP-2 and BMP-4. Mech Dev 92: 193-205.

KWOK, W.K., LING, M.-T., LEE, T.-W., LAU, T.C.M., ZHOU, C., ZHANG, X., CHUA, C.W., CHAN, K.W., CHAN, F.L., GLACKIN, C. et al. (2005). Up-Regulation of TWIST in Prostate Cancer and Its Implication as a Therapeutic Target. Cancer Research 65: 5153-5162.

KYO, S., SAKAGUCHI, J., OHNO, S., MIZUMOTO, Y., MAIDA, Y., HASIMOTO, M., NAKAMURA, M., TAKAKURA, M., NAKAJIMA, M., MASUTOMI, K. et al. (2006). High Twist expression is involved in infiltrative endometrial cancer and affects patient survival. Human Pathology 37: 431-438.

LAURSEN, K.B., MIELKE, E., IANNACCONE, P. and FUCHTBAUER, E.M. (2007). Mechanism of transcriptional activation by the proto-oncogene Twist1. J Biol Chem 282: 34623-34633.

LEE, M.S., LOWE, G., FLANAGAN, S., KUCHLER, K. and GLACKIN, C.A. (2000). Human Dermo-1 has attributes similar to twist in early bone development. Bone 27: 591-602.

LEE, S., SETO, M., SIE, K. and CUNNINGHAM, M. (2002). A child with SaethreChotzen syndrome, sensorineural hearing loss, and a TWIST mutation. Cleft Palate Craniofac J39: 110-114.

LEE, V.M., BRONNER-FRASER, M. and BAKER, C.V. (2005). Restricted response of mesencephalic neural crest to sympathetic differentiation signals in the trunk. Dev Bio/278: 175-192.

LEE, Y.S., LEE, H.H., PARK, J., YOO, E.J., GLACKIN, C.A., CHOI, Y.I., JEON, S.H., SEONG, R.H., PARK, S.D. and KIM, J.B. (2003). Twist2, a novel ADD1/ SREBP1c interacting protein, represses the transcriptional activity of ADD1/ SREBP1c. Nucleic Acids Res 31: 7165-7174.

LEJARD, V., BRIDEAU, G., BLAIS, F., SALINGCARNBORIBOON, R., WAGNER, G., ROEHRL, M.H., NODA, M., DUPREZ, D., HOUILLIER, P. and ROSSERT, J. (2007). Scleraxis and NFATc regulate the expression of the pro-alpha1(I) collagen gene in tendon fibroblasts. J Biol Chem 282: 17665-75.

LEPTIN, M. (1999). Gastrulation in Drosophila: the logic and the cellular mechanisms. EMBO J18: 3187-3192.

LI, L., CSERJESI, P. and OLSON, E.N. (1995). Dermo-1: a novel twist-related bHLH protein expressed in the developing dermis. Dev Bio/172: 280-92.

LI, W. and LI, Y. (2006). Regulation of dHAND protein expression by all-trans retinoic acid through ET-1/ETAR signaling in $\mathrm{H} 9 \mathrm{c} 2$ cells. $J$ Cel/ Biochem 99 : 478-484.

LINCOLN, J., ALFIERI, C.M. and YUTZEY, K.E. (2004). Development of heart valve leaflets and supporting apparatus in chicken and mouse embryos. Dev Dyn230: 239-250.

LINKER, C., LESBROS, C., GROS, J., BURRUS, L.W., RAWLS, A. and MARCELLE, C. (2005). beta-Catenin-dependent Wnt signalling controls the epithelial organisation of somites through the activation of paraxis. Development 132: 3895-3905.

LIU, A., WANG, B. and NISWANDER, L.A. (2005a). Mouse intraflagellar transport proteins regulate both the activator and repressor functions of Gli transcription factors. Development 132: 3103-3111.

LIU, H., MARGIOTTA, J.F. and HOWARD, M.J. (2005b). BMP4 supports noradrenergic differentiation by a PKA-dependent mechanism. Dev Bio/286: 521-536.

LIU, Y., NIFUJI, A., TAMURA, M., WOZNEY, J.M., OLSON, E.N. and NODA, M. (1997a). Scleraxis messenger ribonucleic acid is expressed in C2C12 myoblasts and its level is down-regulated by bone morphogenetic protein-2 (BMP2). J Cell Biochem 67: 66-74.

LIU, Y., WATANABE, H., NIFUJI, A., YAMADA, Y., OLSON, E.N. and NODA, M. (1997b). Overexpression of a single helix-loop-helix-type transcription factor, scleraxis, enhances aggrecan gene expression in osteoblastic osteosarcoma
ROS17/2.8 cells. J Biol Chem 272: 29880-29885.

LOCASCIO, A. and NIETO, M.A. (2001). Cell movements during vertebrate development: integrated tissue behaviour versus individual cell migration. Curr Opin Genet Dev 11: 464-49.

LUCAS, M.E., MULLER, F., RUDIGER, R., HENION, P.D. and ROHRER, H. (2006). The bHLH transcription factor hand2 is essential for noradrenergic differentiation of sympathetic neurons. Development 133: 4015-4024.

MA, L., TERUYA-FELDSTEIN, J. and WEINBERG, R.A. (2007). Tumour invasion and metastasis initiated by microRNA-10b in breast cancer. Nature 449: 682688.

MA, L. and WEINBERG, R.A. (2007). MicroRNAs in malignant progression. Cel/ Cycle 7: 570-572.

MAESTRO, R., DEI TOS, A.P., HAMAMORI, Y., KRASNOKUTSKY, S., SARTORELLI, V., KEDES, L., DOGLIONI, C., BEACH, D.H. and HANNON, G.J. (1999). Twist is a potential oncogene that inhibits apoptosis. Genes Dev13: 2207-2217.

MARTINDILL, D.M. and RILEY, P.R. (2008). Cell cycle switch to endocycle: the nucleolus lends a hand. Cell Cycle 7: 17-23.

MARTINDILL, D.M., RISEBRO, C.A., SMART, N., FRANCO-VISERAS MDEL, M., ROSARIO, C.O., SWALLOW, C.J., DENNIS, J.W. and RILEY, P.R. (2007). Nucleolar release of Hand1 acts as a molecular switch to determine cell fate. Nat Cel/ Bio/9: 1131-1141.

MASSARI, M.E. and MURRE, C. (2000). Helix-loop-helix proteins: regulators of transcription in eucaryotic organisms. Mol Cel/ Bio/20: 429-440.

MCFADDEN, D.G., BARBOSA, A.C., RICHARDSON, J.A., SCHNEIDER, M.D., SRIVASTAVA, D. and OLSON, E.N. (2005). The Hand1 and Hand2 transcription factors regulate expansion of the embryonic cardiac ventricles in a gene dosage-dependent manner. Development 132: 189-201.

MCFADDEN, D.G., CHARITE, J., RICHARDSON, J.A., SRIVASTAVA, D., FIRULLI, A.B. and OLSON, E.N. (2000). A GATA-dependent right ventricular enhancer controls dHAND transcription in the developing heart. Development 127: 5331 5341.

MCFADDEN, D.G., MCANALLY, J., RICHARDSON, J.A., CHARITE, J. and OLSON, E.N. (2002). Misexpression of dHAND induces ectopic digits in the developing limb bud in the absence of direct DNA binding. Development 129: 3077-3088.

MENDIAS, C.L., BAKHURIN, K.I. and FAULKNER, J.A. (2008). Tendons of myostatin-deficient mice are small, brittle, and hypocellular. Proc Nat/ Acad Sci USA 105: 388-393.

MIC, F.A., SIRBU, I.O. and DUESTER, G. (2004). Retinoic acid synthesis controlled by Raldh2 is required early for limb bud initiation and then later as a proximodistal signal during apical ectodermal ridge formation. JBio/ Chem279: 26698-26706.

MORIKAWA, Y. and CSERJESI, P. (2004). Extra-embryonic vasculature development is regulated by the transcription factor HAND1. Development 131: 21952204.

MORIKAWA, Y., D'AUTREAUX, F., GERSHON, M.D. and CSERJESI, P. (2007) Hand2 determines the noradrenergic phenotype in the mouse sympathetic nervous system. Dev Bio/307: 114-126.

MORIKAWA, Y., DAI, Y.S., HAO, J., BONIN, C., HWANG, S. and CSERJESI, P. (2005). The basic helix-loop-helix factor Hand 2 regulates autonomic nervous system development. Dev Dyn 234: 613-621.

MORIN, S., POZZULO, G., ROBITAILLE, L., CROSS, J. and NEMER, M. (2005). MEF2-dependent recruitment of the HAND1 transcription factor results in synergistic activation of target promoters. J Biol Chem 280: 32272-32278.

MUIR, T., SADLER-RIGGLEMAN, I. and SKINNER, M.K. (2005). Role of the basic helix-loop-helix transcription factor, scleraxis, in the regulation of Sertoli cell function and differentiation. Mol Endocrino/ 19: 2164-2174.

MUIR, T., WILSON-RAWLS, J., STEVENS, J.D., RAWLS, A., SCHWEITZER, R., KANG, C. and SKINNER, M.K. (2008). Integration of CREB and bHLH transcriptional signaling pathways through direct heterodimerization of the proteins: Role in muscle and testis development. Mol Reprod Dev.

MULLER, F. and ROHRER, H. (2002). Molecular control of ciliary neuron development: BMPs and downstream transcriptional control in the parasympathetic lineage. Development 129: 5707-5717.

MURAKAMI, M., KATAOKA, K., TOMINAGA, J., NAKAGAWA, O. and KURIHARA, H. (2004). Differential cooperation between dHAND and three different Eproteins. Biochem Biophys Res Commun 323: 168-174. 
MURCHISON, N.D., PRICE, B.A., CONNER, D.A., KEENE, D.R., OLSON, E.N., TABIN, C.J. and SCHWEITZER, R. (2007). Regulation of tendon differentiation by scleraxis distinguishes force-transmitting tendons from muscle-anchoring tendons. Development 134: 2697-2708.

MURCHISON, N.D., PRICE, B.A., CONNER, D.A., KEENE, D.R., OLSON, E.N., TABIN, C.J. and SCHWEITZER, R. (2007). Regulation of tendon differentiation by scleraxis distinguishes force-transmitting tendons from muscle-anchoring tendons. Development 134: 2697-2708.

NAKAYA, Y., KURODA, S., KATAGIRI, Y.T., KAIBUCHI, K. and TAKAHASHI, Y. (2004). Mesenchymal-epithelial transition during somitic segmentation is regulated by differential roles of Cdc42 and Rac1. Dev Cel/7: 425-438.

NATARAJAN, A., YAMAGISHI, H., AHMAD, F., LI, D., ROBERTS, R., MATSUOKA, R., HILL, S. and SRIVASTAVA, D. (2001). Human eHAND, but not dHAND, is down-regulated in cardiomyopathies. J Mol Cel/ Cardio/33: 1607-1614.

O'ROURKE, M.P., SOO, K., BEHRINGER, R.R., HUI, C.C. and TAM, P.P. (2002). Twist plays an essential role in FGF and $\mathrm{SHH}$ signal transduction during mouse limb development. Dev Bio/248: 143-156.

O'ROURKE, M.P. and TAM, P.P. (2002). Twist functions in mouse development. Int $J$ Dev Bio/46: 401-413.

OLSON, E.N. and ROSENTHAL, N. (1994). Homeobox genes and muscle patterning. Cel/79: 9-12.

OVERBEEK, P.A. (1997). Right and left go dHAND and eHAND. Nat Genet16:119121.

PEREZ, A.V., PERRINE, M., BRAINARD, N. and VOGEL, K.G. (2003). Scleraxis (Scx) directs lacZ expression in tendon of transgenic mice. Mech Dev 120: 1153-1163.

PERRIN-SCHMITT, F., BOLCATO-BELLEMIN, A.L., BOURGEOIS, P., STOETZEL, C. and DANSE, J.M. (1997). The locations of the $\mathrm{H}$-twist and $\mathrm{H}$-dermo-1 genes are distinct on the human genome. Biochim Biophys Acta 1360: 1-2.

PRYCE, B.A., BRENT, A.E., MURCHISON, N.D., TABIN, C.J. and SCHWEITZER, R. (2007). Generation of transgenic tendon reporters, ScxGFP and ScxAP, using regulatory elements of the scleraxis gene. Dev Dyn 236: 1677-1682.

RALLIS, C., DEL BUONO, J. and LOGAN, M.P. (2005). Tbx3 can alter limb position along the rostrocaudal axis of the developing embryo. Development 132: 19611970.

RICE, D.P., ABERG, T., CHAN, Y., TANG, Z., KETTUNEN, P.J., PAKARINEN, L., MAXSON, R.E. and THESLEFF, I. (2000). Integration of FGF and TWIST in calvarial bone and suture development. Development 127: 1845-1855.

RILEY, P., ANSON-CARTWRIGHT, L. and CROSS, J.C. (1998). The Hand1 bHLH transcription factor is essential for placentation and cardiac morphogenesis. Nat Genet 18: 271-275.

RILEY, P.R., GERTSENSTEIN, M., DAWSON, K. and CROSS, J.C. (2000). Early exclusion of hand1-deficient cells from distinct regions of the left ventricular myocardium in chimeric mouse embryos. Dev Bio/227: 156-168.

RISEBRO, C.A., SMART, N., DUPAYS, L., BRECKENRIDGE, R., MOHUN, T.J. and RILEY, P.R. (2006). Hand1 regulates cardiomyocyte proliferation versus differentiation in the developing heart. Development 133: 4595-4606.

RUEST, L.B., DAGER, M., YANAGISAWA, H., CHARITE, J., HAMMER, R.E., OLSON, E.N., YANAGISAWA, M. and CLOUTHIER, D.E. (2003). dHAND-Cre transgenic mice reveal specific potential functions of dHAND during craniofacial development. Dev Bio/257: 263-277.

RUEST, L.B., XIANG, X., LIM, K.C., LEVI, G. and CLOUTHIER, D.E. (2004). Endothelin-A receptor-dependent and -independent signaling pathways in establishing mandibular identity. Development 131: 4413-4423.

RYAN, H.E., LO, J. and JOHNSON, R.S. (1998). HIF-1 alpha is required for solid tumor formation and embryonic vascularization. EMBO J17: 3005-3015.

RYCHLIK, J.L., GERBASI, V. and LEWIS, E.J. (2003). The interaction between $\mathrm{dHAND}$ and Arix at the dopamine beta-hydroxylase promoter region is independent of direct dHAND binding to DNA. J Biol Chem 278: 49652-49660.

SALSI, V., VIGANO, M.A., COCCHIARELLA, F., MANTOVANI, R. and ZAPPAVIGNA, V. (2008). Hoxd13 binds in vivo and regulates the expression of genes acting in key pathways for early limb and skeletal patterning. Dev Biol 317: 497-507.

SANDMANN, T., GIRARDOT, C., BREHME, M., TONGPRASIT, W., STOLC, V. and FURLONG, E.E.M. (2007). A core transcriptional network for early meso- derm development in Drosophila melanogaster. Genes Dev21: 436-449.

SCHMIDT, C., STOECKELHUBER, M., MCKINNELL, I., PUTZ, R., CHRIST, B. and PATEL, K. (2004). Wnt 6 regulates the epithelialisation process of the segmental plate mesoderm leading to somite formation. Dev Bio/271: 198-209.

SCHWEITZER, R., CHYUNG, J.H., MURTAUGH, L.C., BRENT, A.E., ROSEN, V., OLSON, E.N., LASSAR, A. and TABIN, C.J. (2001). Analysis of the tendon cell fate using Scleraxis, a specific marker for tendons and ligaments. Development 128: 3855-3866

SEHER, T.C., NARASIMHA, M., VOGELSANG, E. and LEPTIN, M. (2007). Analysis and reconstitution of the genetic cascade controlling early mesoderm morphogenesis in the Drosophila embryo. Mech. Dev. 124: 167-179.

SETO, M.L., HING, A.V., CHANG, J., HU, M., KAPP-SIMON, K.A., PATEL, P.K., BURTON, B.K., KANE, A.A., SMYTH, M.D., HOPPER, R. et al. (2007). Isolated sagittal and coronal craniosynostosis associated with TWIST box mutations. Am J Med Genet A 143: 678-686.

SHUKUNAMI, C., TAKIMOTO, A., ORO, M. and HIRAKI, Y. (2006). Scleraxis positively regulates the expression of tenomodulin, a differentiation marker of tenocytes. Dev Bio/298: 234-247.

SIMMONS, D.G., NATALE, D.R., BEGAY, V., HUGHES, M., LEUTZ, A. and CROSS, J.C. (2008). Early patterning of the chorion leads to the trilaminar trophoblast cell structure in the placental labyrinth. Development 135: 20832091.

SMART, N., HILL, A.A., CROSS, J.C. and RILEY, P.R. (2002). A differential screen for putative targets of the bHLH transcription factor Hand1 in cardiac morphogenesis. Mech Dev 119 Suppl 1: S65-S71.

SMITH, T.G., SWEETMAN, D., PATTERSON, M., KEYSE, S.M. and MUNSTERBERG, A. (2005). Feedback interactions between MKP3 and ERK MAP kinase control scleraxis expression and the specification of rib progenitors in the developing chick somite. Development 132: 1305-1314.

SOKOL, N.S. and AMBROS, V. (2005). Mesodermally expressed Drosophila microRNA-1 is regulated by Twist and is required in muscles during larval growth. Genes Dev 19: 2343-2354.

SOO, K., O'ROURKE, M.P., KHOO, P.L., STEINER, K.A., WONG, N., BEHRINGER, R.R. and TAM, P.P. (2002). Twist function is required for the morphogenesis of the cephalic neural tube and the differentiation of the cranial neural crest cells in the mouse embryo. Dev Bio/247: 251-270.

SOSIC, D., RICHARDSON, J.A., YU, K., ORNITZ, D.M. and OLSON, E.N. (2003). Twist regulates cytokine gene expression through a negative feedback loop that represses NF-kappaB activity. Ce//112: 169-180.

SPICER, D.B., RHEE, J., CHEUNG, W.L. and LASSAR, A.B. (1996). Inhibition of myogenic bHLH and MEF2 transcription factors by the bHLH protein Twist. Science 272: 1476-1480.

SRIVASTAVA, D., CSERJESI, P. and OLSON, E.N. (1995). A subclass of bHLH proteins required for cardiac morphogenesis. Science 270: 1995-1999.

SRIVASTAVA, D., THOMAS, T., LIN, Q., KIRBY, M.L., BROWN, D. and OLSON, E.N. (1997). Regulation of cardiac mesodermal and neural crest development by the bHLH transcription factor, dHAND. Nat Genet 16: 154-160.

STATHOPOULOS, A., VAN DRENTH, M., ERIVES, A., MARKSTEIN, M. and LEVINE, M. (2002). Whole-genome analysis of dorsal-ventral patterning in the Drosophila embryo. Cel/111: 687-701.

STAUDINGER, J., PERRY, M., ELLEDGE, S.J. and OLSON, E.N. (1993). Interactions among vertebrate helix-loop-helix proteins in yeast using the two-hybrid system. J Biol Chem 268: 4608-4611.

STOETZEL, C., WEBER, B., BOURGEOIS, P., BOLCATO-BELLEMIN, A.L. and PERRIN-SCHMITT, F. (1995). Dorso-ventral and rostro-caudal sequential expression of M-twist in the postimplantation murine embryo. Mech Dev 51 251-263

TAKAHASHI, Y., TAKAGI, A., HIRAOKA, S., KOSEKI, H., KANNO, J., RAWLS, A and SAGA, Y. (2007). Transcription factors Mesp2 and Paraxis have critical roles in axial musculoskeletal formation. Dev Dyn 236: 1484-1494.

TAKEUCHI, J.K., OHGI, M., KOSHIBA-TAKEUCHI, K., SHIRATORI, H., SAKAKI, I., OGURA, K., SAIJOH, Y. and OGURA, T. (2003). Tbx5 specifies the left/right ventricles and ventricular septum position during cardiogenesis. Development 130: 5953-5964

TAMURA, M. and NODA, M. (1999). Identification of DERMO-1 as a member of helix-loop-helix type transcription factors expressed in osteoblastic cells. J Cell 
Biochem 72: 167-176.

TANAKA, M., CHEN, Z., BARTUNKOVA, S., YAMASAKI, N. and IZUMO, S. (1999). The cardiac homeobox gene Csx/Nkx2.5 lies genetically upstream of multiple genes essential for heart development. Development 126: 1269-1280.

TE WELSCHER, P., FERNANDEZ-TERAN, M., ROS, M.A. and ZELLER, R. (2002a). Mutual genetic antagonism involving GLI3 and dHAND prepatterns the vertebrate limb bud mesenchyme prior to SHH signaling. Genes Dev 16: 421 426.

TE WELSCHER, P., ZUNIGA, A., KUIJPER, S., DRENTH, T., GOEDEMANS, H.J., MEIJLINK, F. and ZELLER, R. (2002b). Progression of vertebrate limb development through SHH-mediated counteraction of GLI3. Science 298: 827-830.

THATTALIYATH, B.D., FIRULLI, B.A. and FIRULLI, A.B. (2002a). The basic-helixloop-helix transcription factor HAND2 directly regulates transcription of the atrial naturetic peptide gene. J Mo/ Cel/ Cardio/34: 1335-1344.

THATTALIYATH, B.D., LIVI, C.B., STEINHELPER, M.E., TONEY, G.M. and FIRULLI, A.B. (2002b). HAND1 and HAND2 are expressed in the adult-rodent heart and are modulated during cardiac hypertrophy. Biochem Biophys Res Commun 297: 870-875.

THIERY, J.P. (2002). Epithelial-mesenchymal transitions in tumor progression. Nature Reviews Cancer 2: 442-454.

THISSE, B., MESSAL, M.E. and PERRIN-SCHMITT, F. (1987). The twist gene: isolation of a Drosophilazygotic gene necessary for the establishment of dorsoventral pattern. Nucleic Acids Research 15: 3439-3453.

THOMAS, T., KURIHARA, H., YAMAGISHI, H., KURIHARA, Y., YAZAKI, Y., OLSON, E.N. and SRIVASTAVA, D. (1998a). A signaling cascade involving endothelin-1, dHAND and msx1 regulates development of neural-crest-derived branchial arch mesenchyme. Development 125: 3005-3014.

THOMAS, T., YAMAGISHI, H., OVERBEEK, P.A., OLSON, E.N. and SRIVASTAVA, D. (1998b). The bHLH factors, dHAND and eHAND, specify pulmonary and systemic cardiac ventricles independent of left-right sidedness. Dev Bio/196: 228-236.

TOGI, K., KAWAMOTO, T., YAMAUCHI, R., YOSHIDA, Y., KITA, T. and TANAKA, M. (2004). Role of Hand1/eHAND in the dorso-ventral patterning and interventricular septum formation in the embryonic heart. Mol Cel/ Biol24: 4627-4635.

TOGI, K., YOSHIDA, Y., MATSUMAE, H., NAKASHIMA, Y., KITA, T. and TANAKA M. (2006). Essential role of Hand2 in interventricular septum formation and trabeculation during cardiac development. Biochem Biophys Res Commun343: 144-151.

VAN DOREN, M., ELLIS, H.M. and POSAKONY, J.W. (1991). The Drosophila extramacrochaetae protein antagonizes sequence-specific DNA binding by daughterless/achaete-scute protein complexes. Development 113: 245-255.

VASICEK, R., MEINHARDT, G., HAIDWEGER, E., ROTHENEDER, H., HUSSLEIN, P. and KNOFLER, M. (2003). Expression of the human Hand1 gene in trophoblastic cells is transcriptionally regulated by activating and repressing specificity protein (Sp)-elements. Gene 302: 115-127.

VERZI, M.P., AGARWAL, P., BROWN, C., MCCULLEY, D.J., SCHWARZ, J.J. and BLACK, B.L. (2007). The transcription factor MEF2C is required for craniofacia development. Dev Cel/12: 645-652.

VINCENTZ, J.W., BARNES, R.M., RODGERS, R., FIRULLI, B.A., CONWAY, S.J. and FIRULLI, A.B. (2008). An absence of Twist1 results in aberrant cardiac neural crest morphogenesis. Dev Biol. 320:131-139

WAGNER, J., SCHMIDT, C., NIKOWITS, W., JR. and CHRIST, B. (2000). Compartmentalization of the somite and myogenesis in chick embryos are influenced by wnt expression. Dev Bio/228: 86-94.

WILM, B., JAMES, R.G., SCHULTHEISS, T.M. and HOGAN, B.L. (2004). The forkhead genes, Foxc1 and Foxc2, regulate paraxial versus intermediate mesoderm cell fate. Dev Biol271: 176-189.

WILSON-RAWLS, J., HURT, C.R., PARSONS, S.M. and RAWLS, A. (1999). Differential regulation of epaxial and hypaxial muscle development by paraxis. Development 126: 5217-5229.
WILSON-RAWLS, J., RHEE, J.M. and RAWLS, A. (2004). Paraxis is a basic helix loop-helix protein that positively regulates transcription through binding to specific E-box elements. J Biol Chem 279: 37685-37692.

WOLF, C., THISSE, C., STOETZEL, C., THISSE, B., GERLINGER, P. and PERRIN SCHMITT, F. (1991). The M-twist gene of Mus is expressed in subsets of mesodermal cells and is closely related to the XenopusX-twi and the Drosophila twist genes. Dev Bio/143: 363-373.

XU, H., FIRULLI, A.B., ZHANG, X. and HOWARD, M.J. (2003). HAND2 synergistically enhances transcription of dopamine-beta-hydroxylase in the presence of Phox2a. Dev Bio/262: 183-193.

YAMAGISHI, H., YAMAGISHI, C., NAKAGAWA, O., HARVEY, R.P., OLSON, E.N and SRIVASTAVA, D. (2001). The combinatorial activities of Nkx2.5 and dHAND are essential for cardiac ventricle formation. Dev Bio/239: 190-203.

YANAGISAWA, H., CLOUTHIER, D.E., RICHARDSON, J.A., CHARITE, J. and OLSON, E.N. (2003). Targeted deletion of a branchial arch-specific enhancer reveals a role of dHAND in craniofacial development. Development 130: 1069 1078.

YANG, J., MANI, S.A., DONAHER, J.L., RAMASWAMY, S., ITZYKSON, R.A., COME, C., SAVAGNER, P., GITELMAN, I., RICHARDSON, A. and WEINBERG, R.A. (2004). Twist, a master regulator of morphogenesis, plays an essential role in tumor metastasis. Cel/117: 927-939.

YANG, M.H., WU, M.Z., CHIOU, S.H., CHEN, P.M., CHANG, S.Y., LIU, C.J., TENG S.C. and WU, K.J. (2008). Direct regulation of TWIST by HIF-1alpha promotes metastasis. Nat Cel/ Bio/10: 295-305

YEH, L.C., TSAI, A.D. and LEE, J.C. (2005). Cartilage-derived morphogenetic proteins induce osteogenic gene expression in the $\mathrm{C} 2 \mathrm{C} 12$ mesenchymal cell line. J Cell Biochem 95: 173-188

YOSHIDA, T., PHYLACTOU, L.A., UNEY, J.B., ISHIKAWA, I., ETO, K. and ISEKI, $S$. (2005). Twist is required for establishment of the mouse coronal suture. $J$ Anat 206: 437-444.

YU, K., XU, J., LIU, Z., SOSIC, D., SHAO, J., OLSON, E.N., TOWLER, D.A. and ORNITZ, D.M. (2003). Conditional inactivation of FGF receptor 2 reveals an essential role for FGF signaling in the regulation of osteoblast function and bone growth. Development 130: 3063-3074.

ZANG, M.X., LI, Y., WANG, H., WANG, J.B. and JIA, H.T. (2004a). Cooperative interaction between the basic helix-loop-helix transcription factor dHAND and myocyte enhancer factor $2 \mathrm{C}$ regulates myocardial gene expression. J Biol Chem 279: 54258-54263

ZANG, M.X., LI, Y., XUE, L.X., JIA, H.T. and JING, H. (2004b). Cooperative activation of atrial naturetic peptide promoter by dHAND and MEF2C. $J$ Cell Biochem 93: 1255-1266.

ZAVADIL, J. and BOTTINGER, E.P. (2005). TGF-B and epithelial-to-mesenchymal transitions. Oncogene 24: 5764-5774.

ZEISBERG, E.M., MA, Q., JURASZEK, A.L., MOSES, K., SCHWARTZ, R.J., IZUMO, S. and PU, W.T. (2005). Morphogenesis of the right ventricle requires myocardial expression of Gata4. J Clin Invest 115: 1522-1531.

ZHAO, Y., RANSOM, J.F., LI, A., VEDANTHAM, V., VON DREHLE, M., MUTH, A.N., TSUCHIHASHI, T., MCMANUS, M.T., SCHWARTZ, R.J. and SRIVASTAVA, D. (2007). Dysregulation of cardiogenesis, cardiac conduction, and cell cycle in mice lacking miRNA-1-2. Cel/129: 303-317.

ZHAO, Y., SAMAL, E. and SRIVASTAVA, D. (2005). Serum response factor regulates a muscle-specific microRNA that targets Hand2 during cardiogenesis. Nature 436: 214-220.

ZINZEN, R.P., CANDE, J., RONSHAUGEN, M., PAPATSENKO, D. and LEVINE M. (2006). Evolution of the Ventral Midline in Insect Embryos. Dev Ce//11: 895902.

ZUNIGA, A. and ZELLER, R. (1999). Gli3 (Xt) and formin (Id) participate in the positioning of the polarising region and control of posterior limb-bud identity. Development 126: 13-21. 


\section{Further Related Reading, published previously in the Int. J. Dev. Biol.}

See Special Issue Evolution \& Development, edited by edited by Jaume Baguñà and Jordi García Fernández at: http://www.ijdb.ehu.es/web/contents.php?vol=47\&issue=7-8

See Special Issue Limb Development, edited by Juan Hurlé and Juan C. Izpisúa-Belmonte at: http://www.ijdb.ehu.es/web/contents. php?vol=46\&issue $=7$

See Special Issue Developmental Genetics of Drosophila, edited by Alain Ghysen at: http://www.ijdb.ehu.es/web/contents.php?vol=42\&issue $=3$

Identification and developmental expression of Xenopus paraxis

Hsiu-Ting Tseng and Milan Jamrich

Int. J. Dev. Biol. (2004) 48: 1155-1158

Twist functions in mouse development

Meredith P O'Rourke and Patrick P L Tam

Int. J. Dev. Biol. (2002) 46: 401-413

R-twist gene expression during rat palatogenesis

A Bloch-Zupan, N Hunter, A Manthey and J Gibbins

Int. J. Dev. Biol. (2001) 45: 397-404

Developmental expression of chick twist and its regulation during limb patterning A T Tavares, J C Izpisúja-Belmonte and J Rodriguez-León

Int. J. Dev. Biol. (2001) 45: 707-713

The bHLH genes in neural development

$\mathrm{C}$ Dambly-Chaudière and $\mathrm{M}$ Vervoort

Int. J. Dev. Biol. (1998) 42: 269-273

The genetics of the Drosophila achaete-scute gene complex: a historical appraisal J A Campos-Ortega

Int. J. Dev. Biol. (1998) 42: 291-297

5 yr ISI Impact Factor $(2008)=3.271$

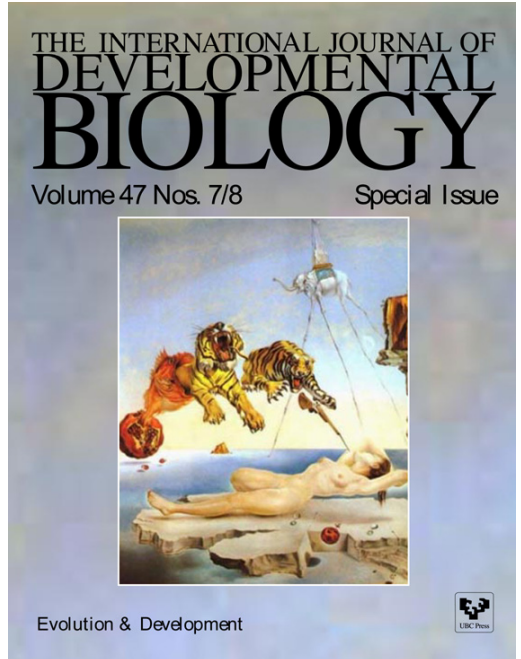

